\title{
ADAPTIVE RESPONSES TO LOW DOSES OF RADIATION OR CHEMICALS: THEIR CELLULAR AND MOLECULAR MECHANISMS
}

Yann Guéguen ${ }^{\#, 1,2}$, Alice Bontemps ${ }^{1}$, Teni G Ebrahimian ${ }^{1}$

${ }^{1}$ Institut de Radioprotection et de Sureté Nucléaire (IRSN), PSE-SANTE, SESANE, LRTOX, Fontenayaux-Roses, France.

${ }^{2}$ Institut de Radioprotection et de Sureté Nucléaire (IRSN), PSE-SANTE, SESANE, LRSI, Fontenay-auxRoses, France.

${ }^{\#}$ Correspondance to:

Yann GUEGUEN

Institut de Radioprotection et de Sureté Nucléaire (IRSN), PSE-SANTE, SESANE, LRSI, Fontenay-auxRoses, France

B.P. $n^{\circ} 17$, F 92262 Fontenay-aux-Roses Cedex, FRANCE.

Ph: 33 - 1583599 78; Fax: 33 - 158358467

E-mail:yann.gueguen@irsn.fr

http://orcid.org/0000-0002-6234-2888

\section{Acknowledgments}

We apologize to the many scientists whose work we were not able to credit due to space restrictions. We thank Joan Francesc Barquinero Estruch (Universitat Autònoma de Barcelona), Klervi Leuraud, Karine Tack and Dominique Laurier (Department of research on the biological and health effects of ionizing radiation, IRSN) for helpful comments and suggestions and Marc Benderitter (Department of research in radiobiology and regenerative medicine, IRSN) for initial discussions on this topic. 


\begin{abstract}
This article reviews the current knowledge on the mechanisms of adaptive response to low doses of ionizing radiation or chemical exposure. A better knowledge of these mechanisms is needed to improve our understanding of health risks at low levels of environmental or occupational exposure and their involvement in cancer or non-cancer diseases. This response is orchestrated through a mul tifaceted cellular program involving the concerted action of diverse stress response pathways. These evolutionary highly conserved defense mechanisms determine the cellular response to chemical and physical aggression. They include DNA damage repair (p53, ATM, PARP pathways), antioxidant response (Nrf2 pathway), immune/inflammatory response (NK$\kappa B$ pathway), cell survival/death pathway (apoptosis), endoplasmic response to stress (UPR response), and other cytoprotective processes including autophagy, cell cycle regulation, and the unfolded protein response. The coordinated action of these processes induced by low-dose radiation or chemicals produces biological effects that are currently estimated with the linear non-threshold model. These effects are controversial. They are difficult to detect because of their low magnitude, the scarcity of events in humans, and the difficulty of corroborating associations over the long term. Improving our understanding of these biological consequences should help humans and their environment by enabling better risk estimates, the revision of radiation protection standards, and possible therapeutic advances.
\end{abstract}

\title{
Keywords
}

Adaptive response, low-dose, signaling pathway, stress response, epigenetic regulation, defense mechanism 


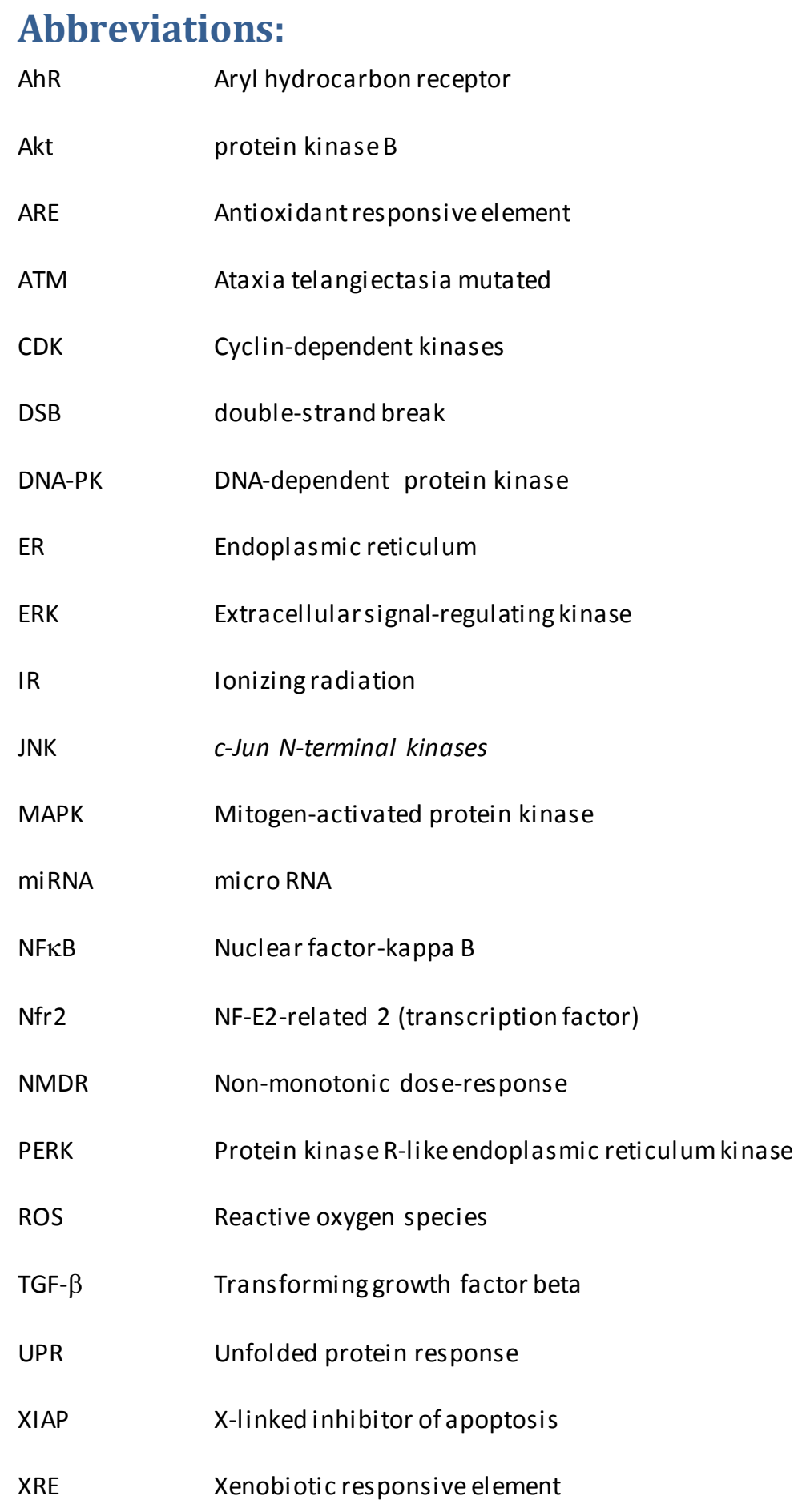




\section{Introduction}

Too little is known about the effects of low levels of exposure to chemicals or radiation, despite the importance of this issue. Because of the varied and polymorphous nature of the various related factors and the consequent difficulty in extrapolating a signal from the diverse background noise, epidemiology alone cannot provide a clear answer. In recent decades, however, the evidence underlying a bundle of presumption appears to show that organisms and cells can adapt to low-dose exposure. Despite discrepancies in some epidemiological and experimental studies, the complementarity of these two approaches should enable advances in answering these questions [1-3].

Various physical and chemical toxic agents, some of them natural (ionizing radiation), others released in the environment by human activity (environmental pollutants), affect organisms, which must adapt continuously to these external fluctuations. Human beings are continuously exposed to natural radiation to low doses (average $2.4 \mathrm{mSv}$ ) from radon, cosmic rays, terrestrial sources and internal emissions of radioactive isotopes in food and water. People are also exposed to anthropogenic sources of radiation used in medicine, research, and industry which contribute to about $20 \%$ of the total radiation exposure. Individual's exposure could then vary due to medical purposes, occupational exposures and living areas [4]. Cell response to these stresses determines whether the organism can function properly and survive. This response is orchestrated through a multifaceted cellular program involving the concerted action of diverse stress response pathways [5] (Figure 1). Many studies demonstrate "non-targeted" effects, including adaptive responses, bystander effects, genomic instability, and coordinated response - a suite of effects that could modulate the relation at low doses between cancer induction and increasing doses of both ionizing radiation (IR) and chemicals. This progress in knowledge about the mechanisms of low-dose biological effects calls for the updating of our understanding of them, particularly the adaptive response.

Two competing hypotheses propose explanations of the effects of exposure to IR or chemicals: the linear nothreshold hypothesis, similar to the basic principle of toxicology first propounded by Paracelsus that "the dose make the poison", and its no-linear relation alternative offered by threshold models [6, 7], which assume that no increase in risk occurs at doses below a certain level. Another variant of this model is the non-monotonic dose-response model (NMDR) [8], according to which low-level exposures to chemicals or radiation might be beneficial for health, even though larger doses are harmful. The NMDR model is valid for some chemical substances and trace elements that the body needs in small amounts to stay healthy, but which may become deleterious when received in larger doses.

Current conventional models of radiation or chemical dose-response relations are inconsistent with these relatively new findings. As long as the mechanisms of the effects remain unclear, modeling low-dose effects is difficult, and its uncertainties are high. Many experimental studies of species ranging from bacteria to human beings subjected to mild stress induced by low doses of IR or other physical or chemical agents describe NMDR $[9-11,8]$ that could be considered beneficial $[12,13]$ or detrimental [14-16]. The low-dose range for chemicals varies substantially according to the substance involved, but for IR UNSCEAR defines low doses as those below $100 \mathrm{mGy}$, moderate doses as from 0.1 to $1 \mathrm{~Gy}$ and high doses as those above $1 \mathrm{~Gy}$ [3]. In this review we focus on the adaptive mechanisms involved after low-dose chemical and radiological exposure at the level of the cell and the organism.

Numerous studies have shown that specific biological mechanisms respond adaptively to low doses of IR or chemicals. Adaptive response can be demonstrated by the ability of a biological system exposed to a small "priming" stress to exhibit a lower detrimental effect on subsequent reception of another higher radiation dose, the "challenge" dose (Figure 1). Thus several reports and publications definea radioadaptive response as "the ability of low dose radiation to induce cellular changes that al ter the level of subsequent radiation induced or spontaneous damage" [17-21,9]. Low doses of IR, likelow doses of chemical agents, might induce biological mechanisms that make the cells better able to cope with subsequent exposures to high doses. The first adaptive response model of low-dose radiation involved a dose range of 1-100 mGy of $\gamma$-rays and postulated that it could be beneficial. Oliveri et al [9] reported fewer chromatid aberrations for cells previously exposed to 
a low concentration of $\left[{ }^{3} \mathrm{H}\right]$ thymidine before acute $\mathrm{x}$-rays than when exposure began only with acute $\mathrm{x}$-rays. The multiple descriptions of low doses stimulating the body's natural defenses in a wide variety of organisms suggest that this phenomenon is evolutionarily conserved [22]. Nevertheless, adaptation does not occur in every system and with all exposure situations.

Adaptive responses to low doses have been convincingly demonstrated in cultured cells, although doubt remains over how they influence risk in multicellular organisms. Mechanistic studies are thus important for reducing uncertainty in the estimation of both cancer and non-cancer diseases. We will describe several underlying mechanisms at the level of molecules, cells, tissues, and organisms. At the molecular level, key signaling pathways have been identified, by their direct induction by IR or chemicals; these include DNA damage response, as well as reactive oxygen species (ROS) and other signaling molecules involved in cell survival. Adaptive processes also occur at the cellular level due to molecular events: via the elimination of damaged organelles (autophagy) or of damaged cells (through apoptosis or necrosis), or by cell cycle delay or the unfolded protein response. Finally, tissue or organism processes can be implicated in this response by inducing cell proliferation or differentiation, controlling immune/inflammatory reactions, inducing toxic substance excretion through transporters, or activating distant cells through bystander/abscopal effects.

The originality of this review lies in its focus on studies showing an adaptive response to low doses of both IR and chemicals and its updating of the mechanisms thus far identified in other recent reviews $[23,16,20]$. Better knowledge of these mechanisms is needed to improve our understanding of health risks at low levels of environmental or occupational exposure and their involvement in cancer or non-cancer diseases.

\section{Molecular mechanisms of intracellular signaling pathways}

These pathways have evolved to overcome cellular perturbation and promote survival of the organism. Figure 2 and Table 1 summarizes the main data about the different signaling pathways involved in the adaptive response to low doses of radiation and chemicals reported in this review. They include the DNA repair pathway, antioxidant response pathway, immune/inflammatory response, cell survival/death pathway, endoplasmic response to stress, and numerous proteins and transcription factors involved in these stress response pathways $[16,24,25]$.

The enhanced expression of stress proteins is considered to be an important adaptive response to adverse conditions such as exposure to chemicals, heavy metals, or IR. They belong to a wide range of defense mechanisms described in this section but also to the cellular and tissue responses detailed further on.

\section{DNA damage response}

To protect the genome integrity, cells possess a sophisticated mechanism of DNA lesions detection and repair, the DNA damage response [26]. Endogenous or exogenous stress can induce several different DNA repair systems, including the mismatch repair, base excision repair, nucleotide excision repair, homologous repair, and non-homologous end joining repair systems.

Many studies have showed that radiation or chemical-induced adaptive responses involve cell cycle regulation and DNA-dependant protein kinases $[27,28]$ (Table 1). Mammalian cells can incur DNA damage from endogenous factors such as oxidative metabolism and from exogenous factors such as exposure to IR or to genotoxic chemicals. The induction of an adaptive response through DNA repair pathway was first shown with alkylating agents. Cells chronically exposed to low non-toxic doses were resistant to the induction of sister chromatid exchange by subsequent exposures to high doses of the same chemical [29]. Olivieri et al. [9] further reported the first description of a radioadaptive response in human lymphocytes: a lower frequency of chromosomal aberrations after a high (challenge) dose in cells previously treated with very low (adaptive) doses of IR. A similar induced adaptive response in human lymphocytes was observed in individuals occupationally exposed to $x$ - or $y$-rays, who had lower dicentric frequencies than did non-occupationally 
exposed individuals [30]. Other authors have shown that the induction of DNA damage repair pathways is an important component of the radioadaptive response [31-33], demonstrating that 3-aminobenzamide blocks it in Iymphocytes and thus suggesting the possible role of repair pathways involving poly(ADP-ribose) polymerase.

Experimental studies have reported the induction of DNA repair mechanisms at low doses of radiation [34]. Others have suggested different factors involved in DNA repair, including DNA-dependent protein kinase (DNAPK) and ERCC5 (XPG) $[35,36]$. Moreover, ataxia telangiectasia mutated (ATM) and p53 tumor suppressor proteins are involved in both cell cycle regulation and DNA repair [27, 35, 37] (Figure 2). The results of these experiments highlight the need for $\mathrm{p} 53$ in the induction of adaptive responses; no such response occurred in p53-deficientcells, such as Trp53 knockout cells, or immortalized cells, such as AT or m5S cells [27]. Similarly, reduced p53 function in mice exposed to low-dose radiation administered at a low dose rate accelerated disease in the modified compared to control mice (with full p53 function) exposed to the same radiation [38]. Several authors have proposed schematic representations summarizing p53 involvement in conjunction with the molecular network relevant to signal transfers and double-strand break (DSB) repair [27, 39]. Some suggest that adaptive response to low-dose IR in eukaryotic cells may involve DSB repair by non-homologous end joining repair pathways. Several protein kinases are reported to activate p53; among them, low-dose irradiation efficiently activates p38MAPK, which inversely is downregulated at high doses [40] (Figure 2).

Borham and Mitchel [41] showed that DNA single-strand breaks are more closely associated with radioresistance induction than the DSBs. Hydroxyl radicals derived from the radiolytic decomposition of $\mathrm{H}_{2} \mathrm{O}$ or from reactive nitrogen species strongly induce these single-strand breaks. This finding is consistent with the increases in protein levels of AP-endonuclease (a DNA base excision repair protein) that occur after a low dose of $\alpha$ particles [42].

\section{Nrf2 mechanisms dependent on and independent of the Nrf2/Keap1 pathway}

Oxidative stress can result in the impairment of DNA and other cell components, such as proteins and lipids. This section develops the major pathway described for the adaptive response to oxidative stress: the Nrf2 pathway. Nrf2 plays a role in controlling the inducible expression of various enzymes responsible for the synthesis of glutathione, direct-acting antioxidants, and reducing equivalents [43].

NF-E2-related 2 (Nrf2) is a transcription factor, and activation of the Nrf2-signaling pathway is an adaptive response to environmental and endogenous stresses. This response renders animals resistant to chemicals and other forms of toxicity by inducing a variety of detoxification or antioxidant enzymes, as reviewed by Osborn and Kensler [44]. This factor belongs to the cap'n collar protein family of basic leucine zipper transcription factors, which bind to the antioxidant responsive element (ARE) and appear essential for maintaining cellular redox balance. Under normal conditions, Keap1 sequesters Nrf2 in the cytoplasm, where Nrf2 then facilitates the degradation of Keap1 via the proteasome.

The Nrf2-antioxidant pathway can be stimulated by irradiation and its preactivation by chemical inducers such as sulforaphane reduce the number of irradiation-induced DNA DSBs $[45,46]$. The induction of this protective Nrf2 function by low-dose IR has also been observed in the diabetic mouse model, where it reduces renal inflammation, oxidative damage, remodeling, and dysfunction [47-49]. This group of authors first showed that low-dose radiation prevented diabetic downregulation of both renal Nrf2 expression and the downstream genes NQO1 and HO-1 [47] (Figure 2, Table 1).

Upregulation of the Nrf2 pathway after low-dose irradiation might also be due to the induction of autophagy. As mention below, low-dose irradiation promotes the autophagy process. A deficiency in autophagy results in competitive inhibition of Nrf2-Keap1 binding by the selective autophagy substrate p62 and stabilizes Nrf2 and its downstream pathway [50]. Other studies have demonstrated that autophagy upregulates Nrf2 by its 
autophagosomal degradation of Keap1 [51] or by upregulation of the oncogene signaling protein and the subsequent induction of the antioxidant pathway [52]. Nrf2 has also been associated with chemoresistance in cancer cell lines. Overexpression of Nrf2 enhances resistance to chemotherapeutic drugs including cisplatin, doxorubicin, and etoposide in breast carcinoma or neuroblastoma cell lines, and downregulation of Nrf2 makes cancer cells more susceptible to these drugs [53]. In 2015, Chen et al [54] also demonstrated that exposure to $50 \mathrm{mGy}$ of $\alpha$-particles induces radioresistance in human lung adenocarcinoma A459 cells after a subsequent exposure to $750 \mathrm{mGy} \alpha$-particleradiation. The initial exposure to $50 \mathrm{mGy}$ triggers an increase in the expression of Nrf2 and its target HO-1. These authors used short-hairpin RNA (shRNA) of Nrf2 and a chemical inhibitor of HO-1 to suppress the induced radioresistance of the $50 \mathrm{mGy} \alpha$-particleradiation and thereby demonstrate Nrf2 pathway involvement.

Although Nrf2 is primarily regulated via its interaction with Keap1, studies have begun to show that it can be regulated independently of Keap1. Nrf2 phosphorylation by several signal transduction pathways, the involvement of epigenetic factors such as microRNAs (miRNAs), and Nrf2 interaction with other proteins also play a role in its activation [55]. mi RNAs can modulate the Nrf2 signaling network either by their involvement in regulating Nrf2 activity (affectors) or by mediating Nrf2 activity (effectors) [56]. At the post-transcriptional level, components of the Nrf2 pathway can be regulated by several miRNAs (miR-28, 34, 144, 200). For example, Wagner et al [57] showed that decreased levels of miR-155 is correlated with increased Nrf2 expression and a severe reduction in the expression of the proinflammatory TNF $\alpha$ gene. Nrf2 is also regulated post-transcriptionally by phosphorylation, ubiquitination, and acetylation via a variety of enzymes affecting its interaction with Keap1 (ERK/JNK, PCK, MAPK/ERK, and p38), by its localization (PKC, CK2, and GSK3 $\beta / F y n$ ) in the nucleus or within the proteasome, its degradation (GSK3 $\beta / \beta \operatorname{TrCP}$ ), or its binding to DNA binding protein (300/CBP, Maf).

Ligands of AhR (aryl hydrocarbon receptor) activate the XRE (xenobiotic responsive element) to induce the expression of many phase I enzymes, such as the cytochrome P450s that produce reactive intermediates able to activate the antioxidant pathway via the ARE (Figure 2). Some of the products of these Nrf2-regulated enzymes can then activate Nrf2 signaling and thereby potentiate the Nrf2 adaptive response. AhR inducers such as TCDD also induce ROS as well as Nrf2 itself and can therefore activate both ARE and XRE pathways [58]. Moreover, Nrf2 possesses an ARE sequence within its own promoter region to enhance the adaptive cell defense response. For example, upregulation of miR-125b through Nrf2 expression regulates the expression of the AhR repressor and thus reduces cisplatin-induced injury [59]. Nrf2 knockout mice consistently abrogate the adaptive increase of miR-125b elicited by cisplatin and thus worsen kidney injury.

This items of evidence shows that the Nrf2 pathway is highly regulated and suggests that a better understanding of the interplay between the pathways involved in cellular processes such as apoptosis, survival, differentiation, and inflammation is essential to clarify the coordinated cell protection that produces adaptation against stressful conditions.

\section{NF- $\mathrm{kB}$ signaling pathway}

The NFאB (nuclear factor-kappa B) family of transcription factors is a master regulator of the both innate and adaptive immune responses [60]. It also controls the expression of genes involved in the repair of damaged DNA and the regulation of molecules that contribute to the control of cell proliferation, survival, or apoptotic cell death (Figure 2). Numerous studies have shown that NFKB, by inducing genes involved in proinflammatory processes, plays a proinflammatory role. Simultaneously, however, reports have described its antiinflammatory role and the induction of leukocyte apoptosis during the resolution of inflammation. The serine/threonine kinase Akt (protein kinase B) pathway is a central node in cell signaling downstream from inflammatory agents or other cell stimuli and appears to be associated with the adaptive response induced by exposure to low doses of IR (Table 1). 
Prasad et al first reported NFKB activation after low to moderate radiation (0.25-2 Gy) in lymphoblastoid cells [61]; it has since been reported in endothelial cells as well [62]. Both studies observed that NFKB binding has a biphasic induction profile and reported transcriptional activities with a first peak at 0.5 Gy and a second at 2 Gy. Rodel et al further showed that the anti-inflammatory properties of low-dose IR may be due to the interrelations between NFKB and TGF- $\beta 1$ (transforming growth factor beta 1 ) in exposed endothelial cells [62]. The induction of X-linked inhibitor of a poptosis (XIAP) expression in the same model demonstrates the role of this protein in modulating NFKB and TGF- $\beta 1$ expression; both contribute to anti-inflammatory effects and the modulation of apoptosis after low-dose IR [63]. Consistently with this finding, other works have demonstrated that low doses of IR reduce the IL-1 $\beta$ secretion by macrophages that results from reduced expression of RelA (p65), p38 MAPK, and Akt, which are up- and downstream signaling molecules of NF-KB [64] (Figure 2). Studies also suggest that Akt activity responds differentially to low-dose IR. Kim et al [65] showed that a 50-mGy exposure stimulates cell proliferation through the transient activation of Raf and Akt but does not change the cell cycle response-related p53 and p21 levels in lung fibroblasts. A 2-Gy dose of IR, however, induces cell cycle arrest by changing these levels.

As described below, the antioxidant enzyme MnSOD is often cited as an important mechanism of the adaptive response to low doses of IR. Increased NF-KB-mediated SOD2 expression (Figure 2, Table 1), producing a radioadaptive response, has followed thiol treatment or constitutive activation of Akt $[66,67]$. Both classes of agents seem to share the same pathway after activation of $\mathrm{NF}-\mathrm{KB}$, which reduces the overall damage induced by the IR challenge dose. Nevertheless, they differ in complexity, with the TNF $\alpha$ signaling pathway implicated in the low-dose radiation-induced response, but not in the thiol-induced pathway [68].

\section{MAPK (ERK/JNK/p38) signaling pathway}

The mitogen-activated protein kinase (MAPK) cascade is essential for the transduction of extracellular signals into specific cellular responses such as cell migration and survival and modulate cellular metabolism [69, 70]. Stress-activated MAPK superfamily can be induced by exposure to IR or chemicals and to adapt to these environmental circumstances. These pathways are regulated by a diverse array of intra- and extracellular stressors, including environmental physical/chemical changes and exposure to inflammatory cytokines. Their activation appears to be associated with cell protection against IR and chemicals and with survival of these stressors. Several studies have suggested that extracellular signal-regulating kinase 1/2 (ERK1/2), a member of this superfamily, plays a critical role in determining the cellular outcome - survival or death - after irradiation

(Table 1). Low IR doses induce ERK1/2 through ATM, its upstream regulator, whereas high-dose exposure results in ATM-independent dephosphorylation of ERK1/2 and thus shuts down prosurvival signaling [71]. Experiments using siRNA and chemical inhibitors have demonstrated that the cell proliferation stimulated by low-dose IR occurs through ERK1/2 and p38 in normal human fibroblasts and thus confirmed the activation of the MAPK pathway in lung fibroblasts exposed to 50-mGy radiation [72].

Studies have also reported that low-dose IR (0.01-0.1 Gy) induces ERK activation in immune lymphoblast cells without altering Akt activation and then induces an adaptive response to a subsequent high-dose radiation challenge (2 Gy) [73]. The authors suggest that activation of the ERK pathway in cells lacking Akt activity is compensatory and might explain the differential sensitivity of non-tumor and tumor cells previously observed by others [74].

Bystander cells exposed to conditioned media from IR-exposed cells (1-2 Gy) or to genotoxic chemicals show transient increases in MAPK phosphorylation [75]. ERK, JNK, and p38 are all activated and then decline and are inhibited, in correlation with a decrease in caspase activity. Asur et al. suggest that activation of ERK and p38 results in the cell cycle arrest of bystander cells and then the activation of proliferative pathways to repair damaged components. Cells that escape repair may then undergo apoptosis through MAPK-mediated pathways. 


\section{Cross-talk between the intracellular pathways}

As noted in the previous sections describing molecular activities, several types of relations enable cells to balance between stress responses (e.g., antioxidant, anti-inflammatory, and autophagy) and regulation of either death signals or the cell cycle. Although our understanding about the common hallmarks of these responses remains incomplete at present, they most likely originate from an overlap of several processes that may be initiated at various thresholds (depending on the pathway) and operate in a staggered manner (Figure 3).

Among these pathways, Nrf2 is a central transcription factor responsible for the basal and inducible expression of proteins involved in oxidative stress response, xenobiotic metabolism, and cytoprotection, but it is also linked to differentiation, proliferation, growth, and apoptosis. Nrf2-regulated genes include antioxidant enzymes, molecular chaperones, DNA repair enzymes, and anti-inflammatory response proteins. Nrf2 activation can suppress NFKB activity and thereby inhibit inflammation. Cross-talk between Nrf2 and AhR or

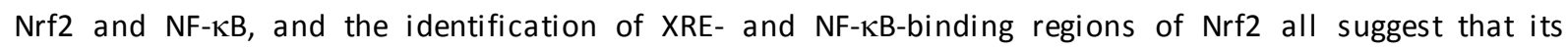
transcription can be regulated by these pathways, as reported in previous sections (Figure 2).

The link between the autophagy process and antioxidative response is an important component of the adaptive response. Several laboratories have shown various a daptive mechanisms of human lung adenocarcinoma A549 cells exposed to low-dose IR before high-dose radiation and confirmed the association between p62, an autophagy adaptor protein, and Keap1, the regulator of Nrf2 antioxidant transcription factor [76, 55]. The sequestration of Keap1 by p62 allows Nrf2 to upregulate ARE-regulated genes.

Links between the antioxidative factor Nrf2 and the UPR (unfolded protein response) pathway are also necessary to alleviate ROS production in the endoplasmic reticulum (ER) during UPR-increased protein folding. Cullinan et al. showed that the Nrf2 pathway is induced by ER stress in a manner depending on protein kinase R-like endoplasmic reticulum kinase (PERK) and that it enhances cell survival [77]. Another example is the interaction of the UPR pathway with apoptosis; toll-like receptor 4 (TLR4) inhibits in a TRIF-dependent manner the UPR-induced expression of CHOP [78], a protein that leads to apoptosis after prolonged induction [79]. Nevertheless, these last interrelations as well as many other links between stress response pathways have only been shown in mechanistic molecular studies but have not yet been demonstrated in an adaptive response process induced by low-dose exposure to physical or chemical stress.

\section{Adaptive mechanisms at the cellular level}

To maintain a stable intracellular environment, cells can respond to physiological stressors or pathological stimuli in various ways, ranging from the activation of survival pathways to the initiation of cell death. The stress response pathways are evolutionary highly conserved defense mechanisms that determine the cellula $r$ response to chemical or physical aggression according to a hierarchical stress model. We present a model adapted from Li et al [80] (Figure 3). At the cell level, these cytoprotective processes include autophagy, which enables cell survival by the degradation and recycling of cell components, cell cycle regulation, which orients cells for repair, proliferation, or differentiation, UPR, which allows re-establishment of normal endoplasmic reticulum function, and apoptosis, that is, programmed cell death induced by excess damage. The bystander response is also described in this chapter as it occurs at the cell level and can involve different signaling pathways.

\section{Autophagy}

Autophagy is a housekeeping survival mechanism that promotes programmed cell survival, sustaining homeostasis by maintaining cellular integrity and favoring efficient cellular function; it is thus distinct from, even antagonistic to, a poptosis or programmed cell death [81]. Autophagy is strongly induced by starvation and is a key component of the adaptive response of cells and organisms to nutrient deprivation, by promoting 
survival until nutrients become available again. It is a nonselective bulk degradative pathway, but also a selective pathway mediated by autophagic adaptor proteins in response to stressful conditions [82]. Its induction by various stimuli (xenobiotics, cytokines, endoplasmic reticulum stress, and oxidative stress) suggests that it plays an essential role in cellular homeostasis and adaptation to adverse environments. Collectively, autophagy antagonizes a poptosis and promotes cell survival via a series of responses to damaged organelles, ER stress, and DNA instability. However, massive and persistent autophagy depletes the cell of organelles and critical proteins and can thus kill severely damaged cells by a caspase-independent form of cell death [83]. Cross-talk between autophagy and apoptosis is manifested by regulatory genes shared with common pathways including $\mathrm{p} 53, \mathrm{Atg} 5$, and $\mathrm{Bcl}-2[81,84]$.

In organs often exposed to stressful conditions, such as the kidney and liver, autophagy promotes cytoprotection and maintains cellularhomeostasis in different cell types through a common mechanism aimed at preventing inflammation, oxidative stress, and apoptosis: the clearance of protein aggregates and unwanted organelles. Autophagy is now accepted to be renoprotective. An increased autophagic flux is observed in renal cell lines and murine models exposed to several nephrotoxins including heavy metals and drugs. The sensitization of kidney cells to hypoxic and ischemia-reperfusion injury by blocking autophagy by knocking out the atg gene suggests autophagy is renoprotective, promoting survival of these kidney cells [85]. Autophagy has also been identified as a critical mechanism for glomerular homeostatic maintenance in response to injuries, contributing to the preservation of structure and function [84]. Autophagy is described increasingly often in vascular diseases such as atherosclerosis, where it is required for endothelial cell alignment and atheroprotection under physiological blood flow [86]. Indeed genetic inactivation of autophagy resulted in major atherosclerosis plaque formation only in areas previously resistant to atherosclerosis, but no increase in the normally atheroprone (low shear stress) areas.

Autophagy can be induced by IR [87-90] or by chemical inducers that confer radioprotective effects [91]. The treatment of hematopoietic cells by carbamazepine before irradiation increases both cell survival, as assessed by clonogenic survival, and autophagy, assayed by immunobl ot for microtubule-associated protein light chain 3 (LC3) [91]. Paglin et al [87] showed that formation of acidic vesicular organelles and autophagy in surviving colonies of cell lines exposed to IR provide long-term protection against damage from low-dose radiation. Exposure to low-dose IR (50 mGy) can also stimulate the autophagy process through the Nrf2 antioxidant pathway. Blockade of the autophagy pathway by an inhibitor suppresses radioresistance and the induction of Nrf2 and HO-1 expression, findings indicating that autophagy mediates Nrf2 upregulation [54].

Exposure to heavy metals at low (subtoxic) doses has also been shown to trigger cell proliferation and autophagy [92]. This study unravel ed the unexpected early upregulation of autophagy in $80 \%$ of cadmium (Cd)treated proximal convoluted tubules in vivo $(<10 \mu \mathrm{M})$, without induction of apoptosis or tubular dysfunction. Induction of endoplasmic reticulum stress was also observed in this study. The authors concluded that autophagy can serve as an early adaptive mechanism but that continuous activation of this process due to cadmium persistence might impair its efficiency and lead to nephrotoxicity in the long term.

In other diseases, such as neuropathies and ischemic heart diseases, autophagy is more widely accepted as beneficial given its role in eliminating "toxic assets" and promoting cell viability. Thus, autophagy has emerged as a new and potent modulator of disease progression.

\section{Cell cycle regulation and apoptosis}

The cellular machinery of the cell cycle is controlled by serine/threonine protein kinases, which are the cyclindependent kinases (CDK). They can stop the cell cycle at different steps if the genome is altered and cause either its repair or apoptosis. The Wnt/beta-catenin pathway plays a critical role in cellular development, survival, proliferation, etc. [93, 94], but the role of this pathway in adaptive response and particularly in immunity is beginning to become more well-defined [95]. The regulatory function of wnt/beta catenin signaling is increased after low dose exposure to ionizing radiation. Indeed, it was shown that low level of irradiation promotes the 
bone marrow stromal cells through the wnt/ßcatenin pathway (Zhang RF, Wang Q, Zhang AA, Xu JG, Zhai LD, Yang XM, Liu XT).

The role of cell cycle regulators of the mitochondrial functions enabling radiation-induced adaptive responses at low doses has been reviewed recently [96]. The authors concluded that the Cyclin B1/CDK1 complex, which is the cell cycle G2/M checkpoint regulator, may be considered a key harmonizer for the regulation of mitochondrial functions in cellular adaptive response to genotoxic stress, including low-dose IR. This kinase complex is one of the main components by which cells communicate with mitochondria under stressing conditions; it plays an important role in coordinating mitochondrial energy production related to cell cycle progression and adaptive response to genotoxic stress. Induced radioadaptation has been reported at doses bel ow 0.6 Gy and attributed to a change in the balance of G2/M checkpoint induction that allows time for DNA repair and increases cell survival. Several studies have demonstrated that low-dose radiation induces an adaptive response via stimulation of normal cell proliferation but does not induce a radioadaptive response in tumor cells $[73,74]$.

Apoptosis is a physiological process of endogenous programmed cell death, mediated by a variety of endogenous and exogenous stimuli including IR. Some miRNAs have been shown to be involved in radioresponsive effects at either high or low doses [97]. These authors suggest a model in which miRNAs may act as "hub" regulators of specific cellular responses, by immediately down-regulating them to stimulate DNA repair mechanisms and then upregulating those involved in suppressing apoptosis for cell survival. They further suggest that among the miRNAs identified miR-608 may contribute to cell cycle arrest. Others have confirmed the decreased apoptosis after low-dose IR and demonstrated it with UV radiation as well [98-100]. Irradiation of human breast epithelial MCF10Acells at $100 \mathrm{mGy}$ produces MnSOD phosphorylation through CyclinB1/CDK1 and then increases resistance to apoptosis induced by a challenge dose of $10 \mathrm{~Gy}$ [101]. In human myeloid cells, low-dose irradiation confers some protection against the induction of apoptosis [102]. Microarray analysis of these cells has identified low-dose inducible genes with known roles in apoptosis regulation and cell cycle regulation. Thus low-dose $\boldsymbol{y}$-radiation modifies apoptotic-related gene expression in freshly isolated blood Iymphocytes, inducing upregulation of $\mathrm{Bcl}-2$, an anti-apoptotic molecule and down-regulation of Bax, a proapoptotic gene [103].

Neurogenesis is another process that may be enhanced by low-dose irradiation [104]. Wei and coauthors related the stimulation of neural stem cell proliferation and reduced neuronal apoptosis in the hippocampus and learning by mice to stimulation of the Wnt/ $\beta$-catenin signaling pathway by 0.3 Gy radiation, whereas they confirmed deleterious effects after a dose of $3 \mathrm{~Gy}$.

\section{The unfolded protein response (UPR)}

The ER is the major cell organelle for the synthesis, folding, and sorting of proteins. The UPR is a protective mechanism for adaptation to environmental stress and recovery of normal ER function. The role of the UPR is to modify cellular functions in response to ER stress and re-establish ER function, by reducing messenger RNA translation, increasing proteasomal degradation, and increasing protein-folding capacity [105, 106]. Under prolonged or unresolvable ER stress, the UPR switches from an adaptive to an apoptotic role. Numerous studies suggest that ER stress and UPR are involved in several pathological situations (ischemia, diabetes, neurodegenerative and renal disorders, and chemical-induced tissue injury) and physiological events (development of different cell types and cytoprotection) [107]. If UPR fails, apoptosis begins. Numerous and widely varied chemicals that perturb calcium signaling, induce ROS production or hypoxia, or deplete amino acids are known to activate the UPR $[108,109]$. The ER is one of the main reservoirs of calcium in the cell, and some divalent metals including lead may replace endogenous divalent cations. It has been reported that lead or cadmium induces ER stress and the corresponding GRP94 and GRP78 calcium-binding chaperones [108]. Knockdown of the latter protein results in an increase in both ROS generation and lead cytotoxicity [110]. The authors suggested that these two ER chaperones (GRP94 and GRP78), as well as the UPR response, may function as a defense mechanism against lead toxicity in coordination with antioxidant enzyme induction. 
In addition to its pathological significance, ER stress/UPR also has physiological and protective effects, as shown, for example, by the cytoprotection of renal cell lines after ER stress by clinically relevant nephrotoxins that induce GRP78 and GRP94 [111]. These results have been confirmed in vitro and in vivo by other authors who have demonstrated that some ER stress inducers, such as heavy metals or pharmacological compounds, trigger UPR, upregulate GRP78, and then activate the autophagy pathway [112-114]. In vivo, these actions result in reducing renal ischemia-reperfusion injury through the improvement of renal function and histology [113]. In vitro binding assays investigating the molecular mechanism show that PERK can directly bind Nrf2 and that tunicamycin, a UPR-inducing agent, triggers Nrf2-DNA binding. Nrf2 is phosphorylated during ER stress responses, thus triggering Nrf2 nuclear import in murine fibroblasts, whereas Nrf2 remains cytoplasmic in PERK -/- cells [77].

\section{The bystander effect}

The bystander effect is a biological/biochemical change expressed by a cell or a tissue that is not directly targeted by IR or chemicals; it happens to cells neighboring or even distant from targeted cells. It was first demonstrated by Nagasawa and Little [115], who found that although $\alpha$-particles traversed less than $1 \%$ of the nuclei of a monolayer cell culture, $30 \%$ of the cells showed increased frequencies of sister chromatid exchanges.

Radiation-induced bystander effects refer to DNA damage-like responses in cells that have not been directly exposed to radiation $[116,117]$. Matsumoto reviewed the interrelation between bystander effects and radioadaptive response in 2007 [10]. A more recent finding is that unexposed bystander cells respond to factors released by targeted cells and thus produce specific responses that can be either deleterious or beneficial [28]. The induction of radioadaptive responses in bystanders depends on the cell type and experimental conditions. Cells that are grown in conditioned medium harvested from cells exposed to low doses of $\alpha$-particles or $\gamma$-rays display increased clonogenic survival after subsequent exposures to radiation $[118,42]$. This phenomenon has also been observed in vivo and appears to resemble abscopal effects, defined as radiation responses in tissues "definitively separate" from the irradiated area [119]. Specific irradiation of human tumor cells in vivo produces a bystander effect in subcutaneously growing tumors [120, 121].

The two main types of intercellular signaling pathways identified as producing radiation-induced bystander responses [122] occur through either cell-cell contact (gap-junction intercellular communication) [123, 124] or secreted diffusible factors (e.g., cytokines, ROS, and miRNAs) $[125,126]$. Low-dose irradiation can induce the selective removal of precancerous cells via intercellular induction of apoptosis. The use of scavengers and inhibitors confirms the involvement of secreted diffusible factors such as cytokines and reactive oxygen/nitrogen species signaling in the selective removal of transformed cells by non-transformed cells in coculture [127]. Nitric oxide (NO) from irradiated cells acts as an intercellular signaling molecule to initiate and activate the early steps in the bystander response process after low-dose irradiation [128]. Epigenetic elements such as DNA methylation may also play a role in regulating low-dose radiation effects through the bystander effect $[129,97]$. DNA methylation regulates low-dose response through reduction of DNA methyltransferases and global DNA methylation in bystander tissues [130] and may inhibit DNA repair [131]. Several data suggest that miRNA changes may have a protective effect after radiation exposure [132]. Recently studies of their role in the bystander response showed that expression levels of some miRNAs, such as miR-21, are modified by fibroblast irradiation and may act on non-irradiated cells [133, 134].

Until recently it has been difficult to demonstrate a bystander response for chemical exposures because treatments expose all cells simultaneously. Nevertheless, new in vitro experimental models have demonstrated the ability of genotoxic agents or chemotherapeutic drugs to induce bystander effects [135-138]. These effects are therefore not specific to IR, and authors have suggested novel mechanisms by which chemotherapeutic agents act on cancer cells. Chemically induced adaptive responses have also been demonstrated in vivo in rats 
pretreated with low doses of cadmium that induce hepatic metallothionein and produce an adaptive tolerance to lethality from a subsequent high dose [139].

\section{Adaptive mechanisms at the tissue and organism levels}

Some biological systems sustain and maintain normal physiology in the organism in response to low or mild stress. These include antioxidant and immune/inflammatory systems, which are particularly active in detoxifying organs such as the kidneys, lung, and liver as well as the vascular system. They sustain and maintain normal physiology in the body in response to such mild stress and protect against toxicity induced by chemicals or radiation. These systems include the adaptive response provided by transporters, but as this is well described in other studies and is specific to chemical exposure, including endocrine disruptors [140], this review will not describe it specifically.

\section{The antioxidant response}

The antioxidant defense system is a key factor that prevents oxidative stress due to by exogenous stress. Mitochondria and ROS appear important to the coordination and regulation of the adaptive response. Because we described the specific role of the Nrf2 pathway above, a more general response by antioxidant enzymes is described here.

The mechanisms of adaptive response have been identified for exposure to heavy metals such as Cd; they involve the induction of metallothioneins (by 10 - to 50 -fold) after low concentration $(<10 \mu \mathrm{M}) \mathrm{Cd}$ pretreatment of rats [139]. The works of Nair et al. [141] confirmed these results and showed that the chronic exposure of rats to low doses of $\mathrm{Cd}$ induces protective mechanisms including the expression of genes for antioxidant enzymes and mitochondrial biogenesis factors. Similarly, we have showed that chronic uranium exposure appears to reinforce the antioxidant system in kidneys, glutathione homeostasis in particular [142]. Uranium is also a heavy metal and a radionuclide known to be nephrotoxic after acute exposure. Chronic exposure at low doses failed to produce nephrotoxic effects but did induce an antioxidative response [142, 143]. These findings suggest that the kidney adapts to uranium during the chronic exposure. Other heavy metals, such as $\mathrm{Hg}, \mathrm{Cu}$, or $\mathrm{Pb}$, may produce protective effects at low concentrations by increasing the expression of antioxidant enzymes, according to Korashy and El-Kadi (2006) [144], who hypothesize that Pb can replace $\mathrm{Zn}$ in the metal-binding site of Keap 1, thereby activating Nrf2 and its downstream proteins HO-1, NQ01, or GSTA1.

High-dose irradiation is particularly known to deactivate antioxidative functions and lead to ROS-induced damage in cells and tissues, while low-dose irradiation or radon inhalation activates antioxidative functions and inhibits ROS-induced damage in in vivo studies [145]: enhanced antioxidative functions have been shown in the brain, lungs, liver and kidneys of mice inhaling radon [145], while low-dose y-irradiation before or after carbon tetrachloride treatment activates antioxidative functions as an adaptive response in mouse liver and inhibits hepatopathy $[146,147]$. The activity of detoxification enzymes such as MnSOD, Catalase, Gpx, and GST has also been reported to rise in cells exposed to low-dose radiation and thus reduce cell damage $[68,148]$. Glutathione content rises after 500-mGy irradiation along with other antioxidants in the liver of mice or in macrophage-like cell lines; this might contribute to a radioadaptive response. Nrf2 plays a role in controlling the inducible expression of various enzymes responsible for the synthesis of glutathione, direct-acting antioxidants, and reducing equivalents.

\section{Immune/inflammatory reactions}

Inflammation is a protective response by cells to pathogens, infections, or tissue damage and serves to destroy or wall off both the injurious agent and the injured tissue. It involves the coordinated communication between different immune cells and blood vessels through an intricate cascade of molecular signals designed to remove the stimulus or initiate the healing process. Observations of changes in the immune system after radiation 
exposure imply that inflammation might also play an essential role in the immunocompetence of living organisms [149]. Recent reviews of several experimental findings reveal that low-dose radiation induces antiinflammatory properties and may thereby protect against inflammatory diseases [150, 151]. Chronic exposure to low-dose radiation of different wild-type mouse strains may stimulate effects that activate the immunological network of the entire body including cell populations and their surface molecules, together with antibody-producing activity [152].

It has been reported that under protracted chronic exposure to low-dose $\gamma$-rays, the normally highly radiosensitive hematopoietic system adapts and becomes radioresistant [153, 152, 149]. Evidence from animal experiments demonstrates that low dose rate irradiation can activate the immune function [154], promoted by enhancement of the proliferative response of splenic and thymic lymphocytes to mitogens, amplification of NK activity, and increased secretion of cytokines that regulate immune cells. Repeated low-dose IR (six fractions of $100 \mathrm{mGy}$ ) also enhances other immune cells or animal models. Kojima et al. [146] observed intensified natural killer activity and antibody-dependent cellular cytotoxicity correlated with the increase in the glutathione level and the suppression of tumor growth in Ehrlich-Solid-Tumor-bearing mice. In vitro, low-dose irradiation is described as activating macrophage cells towards a proinflammatory phenotype [155]. Nonetheless, decreased inflammatory cytokine production, reduced migration, and increased chemotaxis in macrophages ha ve also been observed [156]. A recent study by our group showed the importance of dose rate on endothelial cells' molecular and functional responses; upregulation of antioxidant and anti-inflammatory gene expression after chronic low dose rate exposure ( $6 \mathrm{mGy} / \mathrm{h}$ ) produced an adaptive response even when the dose reached $2 \mathrm{~Gy}$ [157].

Accordingly, the effect of mild stressors such as low-dose irradiation has modulatory anti-inflammatory properties that have been used in preclinical models of low-dose radiotherapy. In vivo models of induced arthritis treated by fractions of irradiation (1-1.5 Gy) are reported to diminish inflammatory proliferation symptoms and thus joint swelling [158-160]. In further studies, histological analys is of arthriticjoints revealed a reduction in clinical symptoms (cartilage and bone destruction) after local irradiation, apparently related to a reduction of iNOS activity and increased expression of heme oxygenase-1 and Hsp70 [161, 162]. Reduced levels of the inflammatory cytokines TNF $\alpha$, IFN $\gamma$, and IL-6 are associated with an improvement in clinical symptoms in another model of induced arthritis in mice, treated by 0.5-Gy per week for five consecutive weeks [163]. Regulatory T cells (Treg) may thus contribute to reducing clinical symptoms in mice treated with low-dose irradiation [164]. In a human TNF-transgenic mouse model of chronic polyarthritis characterized by synovial inflammation, low-dose irradiation of the mice improves the disease's clinical progression [165].

The therapeutic effect of low-dose radiation is also observed in diabetic nephropathy. In a type 2 diabetes mouse model, repeated exposure to low-dose radiation at $25 \mathrm{mGy}$ attenuates diabetes-induced higher renal levels of ICAM-1, TNF- $\alpha$, and PAI-1, three proinflammatory factors involved in the pathogenesis of kidney failure [48]. These results are in line with previous animal studies showing that low-dose radiation modifies the progression of chronic renal failure [166]. As discussed before, the protective mechanisms of enhancing immunity are linked to the antioxidative action of low-dose radiation $[167,168]$. Along with inflammation, oxidative stress is a common feature in chronic kidney diseases; in experimental animals, the ablation of the Nrf2 gene, a critical regulator of cytoprotective factors, causes a lupus-like autoimmune nephritis and exacerbates diabetes-induced oxidative stress, inflammation, and nephropathy $[169,170]$.

The regulation of inflammation in the cells of the vascular tree or other organs often involves an adaptive response by the immune system, associated with an increase in T-reg cells, which control autoreactive T cells and negatively regulate immune response by decreasing proinflammatory lymphocytes and monocytes. Upregulation of T-reg cells is also associated with a decrease in IL-6, which inhibits their production through the action of TGF $\beta$ [171]. In fact, increasing the number of T-reg cells is an adaptive response used by different types of tissue as an immune evasion strategy [172]. In this context, repeated exposure to low-dose mild stressors attenuates inflammation, and upregulate the immunosuppressive T-reg cells response [163, 173]. 
Moreover, inflammation is a hallmark of several cardiovasculardisorders, atherosclerosis in particular. It can be described as a chronic inflammatory disease of the arterial wall in which plaque build-up in the intima impairs normal vascularfunctioning. High doses of IR increase inflammation and atherosclerosis [174-176], while low doses administered at a low dose rate are anti-inflammatory and reduce atherosclerosis in most situations $[177-179,67]$. Recent studies demonstrate the importance of dose rate in the inflammatory response: high dose rates are associated with the upregulation of inflammation, whereas low dose rates induce antiinflammatory responses $[174,177]$. The latter study showed that chronic low-dose ${ }^{137}$ Cs exposure for 6 months reduces levels of the inflammatory mediators CRP, TNF $\alpha$, MCP-1, and IFN- $\gamma$, as well as plaque macrophage content, results that suggest increased plaque stability.

Lung inflammation by benzo[a]pyrene (BaP), a component of cigarette smoke, induces lung tumors in animal models. When human lung fibroblasts were used to study the effect of low-dose radiation on these proinflammatory effects, a single low dose of $90 \mathrm{mGy}$ inhibited the secretion of proinflammatory cytokines (IL6, CXCL1, and CXCL5), probably due to the suppression of IL-6/IL-6R and CLF1/CNFTR signaling [180]. The authors suggest that low-dose $y$-ray exposure suppresses the transformation of human bronchial epithelial cells exposed to BaP by suppressing cytokine secretion. Similarly, the arrest of cancer-facilitating inflammation is a plausible explanation for the reduction of the number of lung tumors by low-dose total body irradiation after their induction by BaP exposure [181].

All these findings indicate that the immune system is modified after low dose exposure to IR or chemicals; the extent and impact of this modification depend on factors such as the IR dose and its temporal relation to the immune system. At low doses and low dose rates, the effects of IR on the immune system may be suppressive or stimulatory, and their long-term impact may have consequences on various human inflammatory pathologies.

\section{Discussion}

The biological effects of low doses of radiation or chemicals are often controversial, in view of the difficulty in detecting noticeable low-level effects or rare events in humans in the short term, despite the great importance of and interest in their long-term biological effects. The development of more sensitive assays is improving the detection of these biological effects at low doses and our understanding of the mechanisms involved. Nevertheless, these effects can include maladaptive responses that may appear beneficial in the short term but may be deleterious over the long term. More specifically, carcinogenesis is an adaptive response process in a given tissue and must thus be understood biologically from its early stages, including DNA repair, tumor promotion, and inflammation. It may therefore play an important role in preventing the immortalization of human cells. The study and understanding of the mechanisms involved in the adaptive response are highly complex as they depend on the model (in vitro, in vivo) used, the endpoint, the dose or the dose rate for radiation, and the interval between exposure and the observed biological effects. Additionally, the duration of the adaptive response can also differ strongly: enzymatic or transcription responses act within minutes or hours) to remodeling, epigenetic, or genomic effects that are observed after months or years [22]. Accordingly, the adaptive response fades if the time between the first and second exposure is too long; inversely, if these exposures follow each other too rapidly, adaptive response mechanisms may not have sufficient time to be induced.

Although some recent epidemiological studies have found significantly elevated risks of solid cancers associated with exposure in the $0-100 \mathrm{mGy}$ dose range, their statistical power remains too limited to investigate risks in the low-dose range with sufficient precision [1]. The biological effects of low-dose radiation or chemicals are currently estimated with the linear non-threshold model, but as EJ Calabrese wrote: "Regulators must extrapolate results not only from animal toxicity studies, typically from mice and/or rats to humans, but also from the very high doses usually used in animal experiments to the very low doses that are 
characteristic of human exposure. These two types of extrapolation are steeped in uncertainty." Calabrese and Baldwin have proposed a quantitative methodology with scoring criteria for beneficial hormetic effects [182]; it has been applied by others to all NMDR for chemicals [8], modified to include a stepwise decision tree to consider individual NMDR relations in a risk assessment context. This is particularly useful for determining the potential impacts of endocrine disrupting chemicals for which NMDR relations have been experimentally described with relatively higher frequency than for other chemicals [140].

Improving our understanding of these biological consequences is essential for protection of humans and their environment, as it will enable better risk estimates, the revision of standards, and, as some authors suggest, translational applications for new therapies. The neurogenic effects of low-dose radiation have led to the exploration of neurodegenerative disorders. Wei and colleagues, for example, showed that parameters reflecting hippocampal neurogenesis and animal learning both increased in the group exposed to low-dose radiation, but confirmed a detrimental effect on neurogenesis in the high-dose group [104]. An evaluation of the protective mechanisms of low-dose radiation in an animal model of type 2 diabetes-induced kidney injury showed that low-dose radiation attenuates dyslipidemia, inflammation, oxidativestress, and fibrosis - that is, the causes of renal damage in type 2 diabetes [48,47]. Moreover, the anti-inflammatory effect of low-dose radiation may protect against other inflammatory diseases, such as arthritis symptoms [150]. Single or fractional administration of low-dose radiation also diminishes inflammatory proliferation (cytokines, iNOS) and is associated with improvement in clinical symptoms (cartilage and bone destruction).

\section{Conclusion}

This review shows the importance of studying low-dose effects while avoiding extrapolations from high-dose studies, which are not sufficient for estimating the real consequences of low-dose exposures. A better understanding of these low-dose effects is underway, through molecular studies that allow us to identify the pathways responsible for the adaptive mechanisms. DNA repair and antioxidative mechanisms are among the best described pathways involved in adaptive response to exposure to low doses of radiation or chemicals. Their interplay with autophagy, inflammatory responses, and UPR can allow the cells to cope with mild stress through a better functional response leading to a higher likelihood of cell survival. If this protection is insufficient and defense mechanisms are overwhelmed, cell death or neoplastic transformation can be observed. In the coming years, a better understanding of the stress response pathway, molecular pathways of toxicity, and the adverse outcome pathway will all be helpful in linking the cellular stress response to organ dysfunction and the risk of an adverse effect on the organism [183]. 


\title{
Figure legends
}

\author{
Fig.1: Cellular processes of stress response pathways (adapted from [184])
}

Fig.2: Crosstalk of signaling pathways between intracellular molecules involved in the adaptive response The figure highlights the different pathways and main factors involved in autophagy, apoptosis, inflammation, antioxidant, DNA damage, UPR and detoxification response

$\mathrm{AhR}$, aryl hydrocarbon receptor; Akt, protein kinase $\mathrm{B}$; AP1, activator protein 1; $\mathrm{ARE}$, antioxidant response element; ATF, activating transcription factor; ATM, ataxia-Telangiectasia Mutated; Atg, autophagy-related ; Bax, Bcl-2-associated X; Bc12, B-cell lymphoma 2; CHOP, C/EBP homologous protein; ER, endoplasmic reticulum; GPx, glutathione peroxidase; IRE1, inositol requiring enzyme 1; ERSE, ER stress-response element ; $\mathrm{IL}$, interleukin ; JNK, c-Jun N-terminal kinases; MAPK, mitogen-activated protein kinase; mTOR, mechanistic target of rapamycin; LC3B, light chain $3 \beta$; NF- $\kappa \mathrm{B}$, nuclear factor-kappa $B$; NRE, $N F-\kappa B$ response element; Nrf2, nuclear factor erythroid 2 (NFE2)-related factor 2; PERK, Protein Kinase RNA-Like ER Kinase; PI3K, phosphatidylinositol-4,5-bisphosphate 3-kinase; ROS, reactive oxygen species; SOD, superoxide dismutase; TLR, Toll-like receptors; TNF, tumor necrosis factor; TRE, 12-O-Tetradecanoylphorbol-13-acetate (TPA) response element; UPR, unfolded protein response; UPRE, unfolded protein response element; XBP-1S, X-box binding protein 1; XIAP, X-linked inhibitor of apoptosis protein; XRE, xenobiotic response element.

Fig.3: Schematic representation of the hierarchical cell stress model in response to chemical or physical stress (adapted from $[80,16]$ )

AhR, Aryl hydrocarbon receptor; ATM, Ataxia-Telangiectasia Mutated; ATF, activating transcription factor; Bax, Bcl-2-associated X; Bcl2, B-cell lymphoma 2; MAPK, Mitogen-activated protein kinases; NF-кB, nuclear factor-kappa B; Nrf-2, nuclear factor erythroid 2 (NFE2)-related factor 2.

\section{Conflict of interest}

The authors declare they have no conflict of interest. 
1. BEIRVII (2006) Health Risks from Exposure to Low Levels of Ionizing Radiation. Committee to Assess Health Risks from Exposure to Low Levels of Ionizing Radiation, National Research Council (U.S.). The National Academies Press

2. Acad. Sci. (Paris). (2005) Dose-effect relationship and estimation of the carcinogenic effects of low doses of ionizing radiation. Joint Report of the Académie des Sciences (Paris) - Académie Nationale de Médecine.

3. UNSCEAR (2012) Biological mechanisms of radiation actions at low doses - A white paper to guide the Scientific Committee's future programme of work. United Nations, New York

4. UNSCEAR (2008) United Nations Scientific Committee on the Effects of Atomic Radiation. Sources and Effects of Ionizing Radiation. Volume I: Report to the General Assembly, Scientific Annexes A and B; Volume II: Scientific Annexes C, D and E. United Nations Scientific Committee on the Effects of Atomic Radiation. UNSCEAR 2008 Report. United Nations Sales publications E.10.XI.3. United Nations, New York.

5. Tang FR, Loke WK (2015) Molecular mechanisms of low dose ionizing radiation-induced hormesis, adaptive responses, radioresistance, bystander effects, and genomic instability. Int J Radiat Biol 91 (1):13-27. doi:10.3109/09553002.2014.937510

6. Heidenreich WF, Paretzke HG, Jacob P (1997) No evidence for increased tumor rates below $200 \mathrm{mSv}$ in the atomic bomb survivors data. Radiat Environ Biophys 36 (3):205-7

7. Hoel DG, Li P (1998) Threshold models in radiation carcinogenesis. Health Phys 75 (3):241-50

8. Lagarde F, Beausoleil C, Belcher SM, Belzunces LP, Emond C, Guerbet M, Rousselle C (2015) Nonmonotonic dose-response relationships and endocrine disruptors: a qualitative method of assessment. Environ Health 14:13. doi:10.1186/1476-069X-14-13

9. Olivieri G, Bodycote J, Wolff S (1984) Adaptive response of human lymphocytes to low concentrations of radioactive thymidine. Science 223 (4636):594-7

10. Matsumoto H, Hamada N, Takahashi A, Kobayashi Y, Ohnishi T (2007) Vanguards of paradigm shift in radiation biology: radiation-induced adaptive and bystander responses. J Radiat Res 48 (2):97-106

11. Feinendegen LE, Brooks AL, Morgan WF (2011) Biological consequences and health risks of low-level exposure to ionizing radiation: commentary on the workshop. Health Phys 100 (3):247-59. doi:10.1097/HP.0b013e31820a83ae

12. Calabrese EJ, Baldwin LA (2003) Hormesis: the dose-response revolution. Annu Rev Pharmacol Toxicol 43:175-97. doi:10.1146/annurev.pharmto x.43.100901.140223

13. Tubiana M, Feinendegen LE, Yang C, Kaminski JM (2009) The linear no-threshold relationship is inconsistent with radiation biologic and experimental data. Radiology 251 (1):13-22. doi:10.1148/radiol.2511080671

14. Pallet N, Anglicheau D, Thervet E (2009) Autophagy is an adaptative mechanism against endoplasmic reticulum stress. Nephrol Dial Transplant 24 (12):3891; author reply 3891. doi:10.1093/ndt/gfp518

15. Barouki R (2010) Linking long-term toxicity of xeno-chemicals with short-term biological adaptation. Biochimie 92 (9):1222-6. doi:10.1016/j.b iochi.2010.02.026

16. Andreau K, Leroux M, Bouharrour A (2012) Health and cellular impacts of air pollutants: from cytoprotection to cytotoxicity. Biochem Res Int 2012:493894. doi:10.1155/2012/493894

17. UNSCEAR (1994) SOURCES AND EFFECTS OF IONIZING RADIATION, United Nations Scientific Committee on the Effects of Atomic Radiation. Report to the General Assembly, with Scientific Annexes. ANNEX B, Adaptive responses to radiation in cells and organisms. United Nations, New York

18. Calabrese EJ, Baldwin LA (2001) The frequency of U-shaped dose responses in the toxicological literature. Toxicol Sci $62(2): 330-8$

19. Szumiel I (2015) Ionizing radiation-induced oxidative stress, epigenetic changes and genomic instability: the pivotal role of mitochondria. Int J Radiat Biol 91 (1):1-12. doi:10.3109/09553002.2014.934929

20. Tapio S, Jacob V (2007) Radioadaptive response revisited. Radiat Environ Biophys 46 (1):1-12. doi:10.1007/s00411-006-0078-8

21. Rigaud O, Moustacchi E (1996) Radioadaptation for gene mutation and the possible molecular mechanisms of the adaptive response. Mutat Res 358 (2):127-34

22. Sthijns MM, Weseler AR, Bast A, Haenen GR (2016) Time in Redox Adaptation Processes: From Evolution to Hormesis. Int J Mol Sci 17 (10). doi:10.3390/ijms 17101649

23. Calabrese EJ (2013) Hormetic mechanisms. Crit Rev Toxicol 43 (7):580-606. doi:10.3109/10408444.2013.808172

24. Jennings P, Limonciel A, Felice L, Leonard MO (2013) An overview of transcriptional regulation in response to toxicological insult. Arch Toxicol 87 (1):49-72. doi:10.1007/s00204-012-0919-y 
25. Wink S, Hiemstra S, Huppelschoten S, Danen E, Niemeijer M, Hendriks G, Vrieling H, Herpers B, van de Water B (2014) Quantitative high content imaging of cellular adaptive stress response pathways in toxicity for chemical safety assessment. Chem Res Toxicol 27 (3):338-55. doi:10.1021/tx4004038

26. Harper JW, Elledge SJ (2007) The DNA damage response: ten years after. Mol Cell 28 (5):739-45. doi:10.1016/j.molcel.2007.11.015

27. Sasaki MS, Ejima Y, Tachibana A, Yamada T, Ishizaki K, Shimizu T, Nomura T (2002) DNA damage response pathway in radioadaptive response. Mutat Res 504 (1-2):101-18

28. Nenoi M, Wang B, Vares G(2015) In vivo radioadaptive response: a review of studies relevant to radiation induced cancer risk. Hum Exp Toxicol 34 (3):272-83. doi:10.1177/0960327114537537

29. Samson L, Schwartz JL (1980) Evidence for an adaptive DNA repair pathway in CHO and human skin fibroblast cell lines. Nature 287 (5785):861-3

30. Barquinero JF, Barrios L, Caballin MR, Miro R, Ribas M, Subias A, Egozcue J (1995) Occupational exposure to radiation induces an adaptive response in human lymphocytes. Int J Radiat Biol 67 (2):18791

31. Joiner MC, Lambin P, Marples B (1999) Adaptive response and induced resistance. C R Acad Sci III 322 (23):167-75

32. Wiencke JK, Afzal V, Olivieri G, Wolff S (1986) Evidence that the $[3 \mathrm{H}]$ thymidine-induced adaptive response of human lymphocytes to subsequent doses of X-rays involves the induction of a chromosomal repair mechanism. Mutagenesis $1(5): 375-80$

33. Wolff S (1992) Failla Memorial Lecture. Is radiation all bad? The search for adaptation. Radiat Res 131 (2): $117-23$

34. Le XC, Xing JZ, Lee J, Leadon SA, Weinfeld M (1998) Inducible repair of thymine glycol detected by an ultrasensitive assay for DNA damage. Science 280 (5366):1066-9

35. Coleman MA, Yin E, Peterson LE, Nelson D, Sorensen K, Tucker JD, Wyrobek AJ (2005) Low-dose irradiation alters the transcript profiles of human lymphoblastoid cells including genes as sociated with cytogenetic radioadaptive response. Radiat Res 164 (4 Pt 1):369-82

36. Takahashi A, Asakawa I, Yuki K, Matsumoto T, Kumamoto M, Kondo N, Ohnishi K, Tachibana A, Ohnishi $\mathrm{T}$ (2002) Radiation-induced apoptosis in the scid mouse spleen after low dose-rate irradiation. Int $\mathbf{J}$ Radiat Biol 78 (8):689-93. doi:10.1080/09553000210132306

37. Nosel I, Vaurijoux A, Barquinero JF, Gruel G (2013) Characterization of gene expression profiles at low and very low doses of ionizing radiation. DNA Repair (Amst) 12 (7):508-17. doi:10.1016/j.dnarep.2013.04.021

38. Mitchel RE (2015) Adaption By Low Dose Radiation Exposure: A Look at Scope and Limitations for Radioprotection. Dose Response 13 (1). doi:10.2203/dose-response.14-025.Mitchel

39. Wang X, Ohnishi T (1997) p53-dependent signal transduction induced by stress. J Radiat Res 38 (3):179-94

40. Shimizu T, Kato T, Jr., Tachibana A, Sasaki MS (1999) Coordinated regulation of radioadaptive response by protein kinase $\mathrm{C}$ and p38 mitogen-activated protein kinase. Exp Cell Res 251 (2):424-32. doi:10.1006/excr. 1999.4582

41. Boreham DR, Mitchel RE (1991) DNA lesions that signal the induction of radioresistance and DNA repair in yeast. Radiat Res $128(1): 19-28$

42. Iyer R, Lehnert BE (2002) Alpha-particle-induced increases in the radioresistance of normal human bystander cells. Radiat Res 157 (1):3-7

43. Lee JM, Li J, Johnson DA, Stein TD, Kraft AD, Calkins MJ, Jakel RJ, Johnson JA (2005) Nrf2, a multiorgan protector? FASEB J 19 (9):1061-6. doi:10.1096/fj.04-2591hyp

44. Osburn WO, Kensler TW (2008) Nrf2 signaling: an adaptive response pathway for protection against environmental toxic insults. Mutat Res 659 (1-2):31-9. doi:10.1016/j.mrrev.2007.11.006

45. Khan NM, Sandur SK, Checker R, Sharma D, Poduval TB, Sainis KB (2011) Pro-oxidants ameliorate radiation-induced apoptosis through activation of the calcium-ERK1/2-Nrf2 pathway. Free Radic Biol Med 51 (1):115-28. doi:10.1016/j.freeradbio med.2011.03.037

46. Mathew ST, Bergstrom P, Hammarsten O (2014) Repeated Nrf2 stimulation using sulforaphane protects fibroblasts from ionizing radiation. Toxicol Appl Pharmacol 276 (3):188-94. doi:10.1016/j.taap.2014.02.013

47. Xing X, Zhang C, Shao M, Tong Q, Zhang G, Li C, Cheng J, Jin S, Ma J, Wang G, Li X, Cai L (2012) Lowdose radiation activates Akt and Nrf2 in the kidney of diabetic mice: a potential mechanism to prevent diabetic nephropathy. Oxid Med Cell Longev 2012:291087. doi:10.1155/2012/291087

48. Shao M, Lu X, Cong W, Xing X, Tan Y, Li Y, Li X, Jin L, Wang X, Dong J, Jin S, Zhang C, Cai L (2014) Multiple low-dose radiation prevents type 2 diabetes-induced renal damage through attenuation of dyslipidemia and insulin resistance and subsequent renal inflammation and oxidative stress. PLoS One 9 (3):e92574. doi:10.1371/journal.pone.0092574 
49. Zhang C, Xing X, Zhang F, Shao M, Jin S, Yang H, Wang G, Cui J, Cai L, Li W, Lu X (2014) Low-dose radiation induces renal SOD1 expression and activity in type 1 diabetic mice. Int J Radiat Biol 90 (3):224-30. doi:10.3109/09553002.2014.877174

50. Komatsu M, Kurokawa H, Waguri S, Taguchi K, Kobayashi A, Ichimura Y, Sou YS, Ueno I, Sakamoto A, Tong KI, Kim M, Nishito Y, Iemura S, Natsume T, Ueno T, Kominami E, Motohashi H, Tanaka K, Yamamoto M (2010) The selective autophagy substrate p62 activates the stress responsive transcription factor Nrf2 through inactivation of Keap1. Nat Cell Biol 12 (3):213-23. doi:10.1038/ncb2021

51. Taguchi K, Fujikawa N, Komatsu M, Ishii T, Unno M, Akaike T, Motohashi H, Yamamoto M (2012) Keap1 degradation by autophagy for the maintenance of redox homeostasis. Proc Natl Acad Sci U S A 109 (34):13561-6. doi:10.1073/pnas.1121572109

52. DeNicola GM, Karreth FA, Humpton TJ, Gopinathan A, Wei C, Frese K, Mangal D, Yu KH, Yeo CJ, Calhoun ES, Scrimieri F, Winter JM, Hruban RH, Iacobuzio-Donahue C, Kern SE, Blair IA, Tuveson DA (2011) Oncogene-induced Nrf2 transcription promotes ROS detoxification and tumorigenesis. Nature 475 (7354):106-9. doi:10.1038/nature10189

53. Wang XJ, Sun Z, Villeneuve NF, Zhang S, Zhao F, Li Y, Chen W, Yi X, Zheng W, Wondrak GT, Wong PK, Zhang DD (2008) Nrf2 enhances resistance of cancer cells to chemotherapeutic drugs, the dark side of Nrf2. Carcinogenes is 29 (6):1235-43. doi:10.1093/carcin/bgn095

54. Chen N, Wu L, Yuan H, Wang J (2015) ROS/Autophagy/Nrf2 Pathway Mediated Low-Dose Radiation Induced Radio-Resistance in Human Lung Adenocarcinoma A549 Cell. Int J Biol Sci 11 (7):833-44. doi:10.7150/ijbs. 10564

55. Bryan HK, Olayanju A, Goldring CE, Park BK (2013) The Nrf2 cell defence pathway: Keap1-dependent and -independent mechanisms of regulation. Biochem Pharmacol 85 (6):705-17. doi:10.1016/j.bcp.2012.11.016

56. Ayers D, Baron B, Hunter T (2015) miRNA Influences in NRF2 Pathway Interactions within Cancer Models. J Nucleic Acids 2015:143636. doi:10.1155/2015/143636

57. Wagner AE, Boesch-Saadatmandi C, Dose J, Schultheiss G, Rimbach G (2012) Anti-inflammatory potential of allyl-isothiocyanate--role of Nrf2, NF-(kappa) B and microRNA-155. J Cell Mol Med 16 (4):836-43. doi:10.1111/j. 1582-4934.2011.01367.x

58. Miao W, Hu L, Scrivens PJ, Batist G (2005) Transcriptional regulation of NF-E2 p45-related factor (NRF2) expression by the aryl hydrocarbon receptor-xenobiotic response element signaling pathway: direct cross-talk between phase I and II drug-metabolizing enzymes. J Biol Chem 280 (21):20340-8. doi:10.1074/jbc.M412081200

59. Joo MS, Lee CG, Koo JH, Kim SG (2013) miR-125b transcriptionally increased by Nrf2 inhibits AhR repressor, which protects kidney from cisplatin-induced injury. Cell Death Dis 4:e899. doi:10.1038/cddis 2013.427

60. Hayden MS, Ghosh S (2011) NF-kappaB in immunobiology. Cell Res 21 (2):223-44. doi:10.1038/cr.2011.13

61. Prasad AV, Mohan N, Chandrasekar B, Meltz ML (1994) Activation of nuclear factor kappa B in human lymphoblastoid cells by low-dose ionizing radiation. Radiat Res 138 (3):367-72

62. Rodel F, Hantschel M, Hildebrandt G, Schultze-Mosgau S, Rodel C, Herrmann M, Sauer R, Voll RE (2004) Dose-dependent biphasic induction and transcriptional activity of nuclear factor kappa B (NF-kappaB) in EA.hy.926 endothelial cells after low-dose X-irradiation. Int J Radiat Biol 80 (2):115-23. doi:10.1080/09553000310001654701

63. Rodel F, Frey B, Capalbo G, Gaipl U, Keilholz L, Voll R, Hildebrandt G, Rodel C (2010) Discontinuous induction of X-linked inhibitor of apoptosis in EA.hy.926 endothelial cells is linked to NF-kappaB activation and mediates the anti-inflammatory properties of low-dose ionising-radiation. Radiother Oncol 97 (2):346-51. doi:10.1016/j.radonc.2010.01.013

64. Lodermann B, Wunderlich R, Frey S, Schorn C, Stangl S, Rodel F, Keilholz L, Fietkau R, Gaipl US, Frey B (2012) Low dose ionising radiation leads to a NF-kappaB dependent decreased secretion of active ILlbeta by activated macrophages with a discontinuous dose-dependency. Int J Radiat Biol 88 (10):72734. doi:10.3109/09553002.2012.689464

65. Kim CS, Kim JK, Nam SY, Yang KH, Jeong M, Kim HS, Jin YW, Kim J (2007) Low-dose radiation stimulates the proliferation of normal human lung fibroblasts via a transient activation of Raf and Akt. Mol Cells 24 (3):424-30

66. Murley JS, Kataoka Y, Weydert CJ, Oberley LW, Grdina DJ (2006) Delayed radioprotection by nuclear transcription factor kappaB -mediated induction of manganese superoxide dismutase in human microvascular endothelial cells after exposure to the free radical scavenger WR1065. Free Radic Biol Med 40 (6):1004-16. doi:10.1016/j.freeradbio med.2005.10.060

67. Park HS, Seong KM, Kim JY, Kim CS, Yang KH, Jin YW, Nam SY (2013) Chronic low-dose radiation inhibits the cells death by cytotoxic high-dose radiation increasing the level of AKT and acinus proteins via NF-kappaB activation. Int J Radiat Biol 89 (5):371-7. doi:10.3109/09553002.2013.754560 
68. Murley JS, Baker KL, Miller RC, Darga TE, Weichselbaum RR, Grdina DJ (2011) SOD2-mediated adaptive responses induced by low-dose ionizing radiation via TNF signaling and amifostine. Free Radic Biol Med 51 (10):1918-25. doi:10.1016/j. free radbio med.2011.08.032

69. Lake D, Correa SA, Muller J (2016) Negative feedback regulation of the ERK1/2 MAPK pathway. Cell Mol Life Sci 73 (23):4397-4413. doi:10.1007/s00018-016-2297-8

70. McKay MM, Morris on DK (2007) Integrating signals from RTKs to ERK/MAPK. Oncogene 26 (22):311321. doi:10.1038/sj.onc.1210394

71. Dent P, Yacoub A, Fisher PB, Hagan MP, Grant S (2003) MAPK pathways in radiation responses. Oncogene 22 (37):5885-96. doi:10.1038/sj.onc.1206701

72. Kim CS, Kim JM, Nam SY, Yang KH, Jeong M, Kim HS, Lim YK, Jin YW, Kim J (2007) Low-dose of ionizing radiation enhances cell proliferation via transient ERK1/2 and p38 activation in normal human lung fibroblasts. J Radiat Res 48 (5):407-15

73. Park HS, You GE, Yang KH, Kim JY, An S, Song JY, Lee SJ, Lim YK, Nam SY (2015) Role of AKT and ERK pathways in controlling sensitivity to ionizing radiation and adaptive response induced by lowdose radiation in human immune cells. Eur J Cell Biol 94 (12):653-60. doi:10.1016/j.ejcb.2015.08.003

74. Yu H, Liu N, Wang H, Shang Q, Jiang P, Zhang Y (2013) Different responses of tumor and normal cells to low-dose radiation. Contemp Oncol (Pozn) 17 (4):356-62. doi:10.5114/wo.2013.35289

75. Asur R, Balasubramaniam M, Marples B, Thomas RA, Tucker JD (2010) Involvement of MAPK proteins in bystander effects induced by chemicals and ionizing radiation. Mutat Res 686 (1-2):15-29. doi:10.1016/j.mrfmmm.2009.12.007

76. Jiang T, Harder B, Rojo de la Vega M, Wong PK, Chapman E, Zhang DD (2015) p62 links autophagy and Nrf2 signaling. Free Radic Biol Med 88 (Pt B):199-204. doi:10.1016/j. freeradbiomed.2015.06.014

77. Cullinan SB, Zhang D, Hannink M, Arvisais E, Kaufman RJ, Diehl JA (2003) Nrf2 is a direct PERK substrate and effector of PERK-dependent cell survival. Mol Cell Biol 23 (20):7198-209

78. Woo CW, Cui D, Arellano J, Dorweiler B, Harding H, Fitzgerald KA, Ron D, Tabas I (2009) Adaptive suppression of the ATF4-CHOP branch of the unfolded protein response by toll-like receptor signalling. Nat Cell Biol 11 (12):1473-80. doi:10.1038/ncb1996

79. Zinszner H, Kuroda M, Wang X, Batchvarova N, Lightfoot RT, Remotti H, Stevens JL, Ron D (1998) CHOP is implicated in programmed cell death in response to impaired function of the endoplasmic reticulum. Genes Dev 12 (7):982-95

80. Li N, Hao M, Phalen RF, Hinds WC, Nel AE (2003) Particulate air pollutants and asthma. A paradigm for the role of oxidative stress in PM-induced adverse health effects. Clin Immunol 109 (3):250-65

81. Kroemer G, Marino G, Levine B (2010) Autophagy and the integrated stress response. Mol Cell 40 (2):28093. doi:10.1016/j.molcel.2010.09.023

82. Zhang Q, Kang R, Zeh HJ, 3rd, Lotze MT, Tang D (2013) DAMPs and autophagy: cellular adaptation to injury and unscheduled cell death. Autophagy 9 (4):451-8. doi:10.4161/auto.23691

83. Scarlatti F, Granata R, Meijer AJ, Codogno P (2009) Does autophagy have a license to kill mammalian cells? Cell Death Differ 16 (1):12-20. doi:10.1038/cdd.2008.101

84. Fougeray S, Pallet N (2015) Mechanisms and biological functions of autophagy in diseased and ageing kidneys. Nat Rev Nephrol 11 (1):34-45. doi:10.1038/nrneph.2014.201

85. Jiang M, Liu K, Luo J, Dong Z (2010) Autophagy is a renoprotective mechanism during in vitro hypoxia and in vivo ischemia-reperfusion injury. Am J Pathol 176 (3):1181-92. doi:10.2353/ajpath.2010.090594

86. Vion AC, Kheloufi M, Hammoutene A, Poisson J, Lasselin J, Devue C, Pic I, Dupont N, Busse J, Stark K, Lafaurie-Janvore J, Barakat AI, Loyer X, Souyri M, Viollet B, Julia P, Tedgui A, Codogno P, Boulanger CM, Rautou PE (2017) Autophagy is required for endothelial cell alignment and atheroprotection under physiological blood flow. Proc Natl Acad Sci U S A 114 (41):E8675-E8684. doi:10.1073/pnas.1702223114

87. Paglin S, Hollister T, Delohery T, Hackett N, McMahill M, Sphicas E, Domingo D, Yahalom J (2001) A novel response of cancer cells to radiation involves autophagy and formation of acidic vesicles. Cancer Res $61(2): 439-44$

88. Paglin S, Lee NY, Nakar C, Fitzgerald M, Plotkin J, Deuel B, Hackett N, McMahill M, Sphicas E, Lampen N, Yahalom J (2005) Rapamycin-sensitive pathway regulates mitochondrial membrane potential, autophagy, and survival in irradiated MCF-7 cells. Cancer Res 65 (23):11061-70. doi:10.1158/00085472.CAN-05-1083

89. Paglin S, Yahalom J (2006) Pathways that regulate autophagy and their role in mediating tumor response to treatment. Autophagy 2 (4):291-3

90. Zois CE, Koukourakis MI (2009) Radiation-induced autophagy in normal and cancer cells: towards novel cytoprotection and radio-sensitization policies? Autophagy 5 (4):442-50 
91. Kim H, Bernard ME, Flickinger J, Epperly MW, Wang H, Dixon TM, Shields D, Houghton F, Zhang X, Greenberger JS (2011) The autophagy-inducing drug carbamazepine is a radiation protector and mitigator. Int J Radiat Biol 87 (10):1052-60. doi:10.3109/09553002.2011.587860

92. Chargui A, Zekri S, Jacquillet G, Rubera I, Ilie M, Belaid A, Duranton C, Tauc M, Hofman P, Poujeol P, El May MV, Mograbi B (2011) Cadmium-induced autophagy in rat kidney: an early biomarker of subtoxic exposure. Toxicol Sci 121 (1):31-42. doi:10.1093/toxsci/kfr031

93. Clevers H, Nusse R (2012) Wnt/beta-catenin signaling and disease. Cell 149 (6):1192-205. doi:10.1016/j.cell.2012.05.012

94. van Amerongen R, Nusse R (2009) Towards an integrated view of Wnt signaling in development. Development 136 (19):3205-14. doi:10.1242/dev.033910

95. Staal FJ, Luis TC, Tiemessen MM (2008) WNT signalling in the immune system: WNT is spreading its wings. Nat Rev Immunol 8 (8):581-93. doi:10.1038/nri2360

96. Alexandrou AT, Li JJ (2014) Cell cycle regulators guide mitochondrial activity in radiation-induced adaptive response. Antioxid Redox Signal 20 (9):1463-80. doi:10.1089/ars.2013.5684

97. Maes OC, An J, Sarojini H, Wu H, Wang E (2008) Changes in MicroRNA expression patterns in human fibroblasts after low-LET radiation. J Cell Biochem 105 (3):824-34. doi:10.1002/jcb.21878

98. Kern P, Keilholz L, Forster C, Seegenschmiedt MH, Sauer R, Herrmann M (1999) In vitro apoptosis in peripheral blood mononuclear cells induced by low-dose radiotherapy displays a discontinuous dosedependence. Int J Radiat Biol 75 (8):995-1003

99. Kern PM, Keilholz L, Forster C, Stach C, Beyer TD, Gaipl US, Kalden JR, Hallmann R, Herrmann M (2000) UVB-irradiated T-cells undergoing apoptosis lose L-selectin by metalloprotese-mediated shedding. Int J Radiat Biol 76 (9):1265-71

100. Gaipl US, Meister S, Lodermann B, Rodel F, Fietkau R, Herrmann M, Kern PM, Frey B (2009) Activationinduced cell death and total Akt content of granulocytes show a biphasic course after low-dose radiation. Autoimmunity 42 (4):340-2

101. Candas D, Fan M, Nantajit D, Vaughan AT, Murley JS, Woloschak GE, Grdina DJ, Li JJ (2013) CyclinB1/Cdk1 phosphorylates mitochondrial antioxidant MnSOD in cell adaptive response to radiation stress. J Mol Cell Biol 5 (3):166-75. doi:10.1093/jmcb/mjs 062

102. Amundson SA, Lee RA, Koch-Paiz CA, Bittner ML, Meltzer P, Trent JM, Fornace AJ, Jr. (2003) Differential responses of stress genes to low dose-rate gamma irradiation. Mol Cancer Res 1 (6):445-52

103. Azimian H, Bahreyni-Toossi MT, Rezaei AR, Rafatpanah H, Hamzehloei T, Fardid R (2015) Up-regulation of Bcl-2 expression in cultured human lymphocytes after exposure to low doses of gamma radiation. $\mathrm{J}$ Med Phys 40 (1):38-44. doi:10.4103/0971-6203.152249

104. Wei LC, Ding YX, Liu YH, Duan L, Bai Y, Shi M, Chen LW (2012) Low-dose radiation stimulates $\mathrm{Wnt} /$ beta-catenin signaling, neural stem cell proliferation and neurogenes is of the mouse hippocampus in vitro and in vivo. Curr Alzheimer Res 9 (3):278-89

105. Zhao L, Ackerman SL (2006) Endoplasmic reticulum stress in health and disease. Curr Opin Cell Biol 18 (4):444-52. doi:10.1016/j.ceb.2006.06.005

106. Pallet N, Fougeray S, Beaune P, Legendre C, Thervet E, Anglicheau D (2009) Endoplasmic reticulum stress: an unrecognized actor in solid organ transplantation. Transplantation 88 (5):605-13. doi:10.1097/TP.0b 013e 3181b22cec

107. Kaufman RJ (2002) Orchestrating the unfolded protein response in health and disease. J Clin Inves t 110 (10):1389-98. doi:10.1172/JCI16886

108. Kitamura M (2008) Endoplasmic reticulum stress in the kidney. Clin Exp Nephrol 12 (5):317-25. doi:10.1007/s 10157-008-0060-7

109. La Rovere RM, Roest G, Bultynck G, Parys JB (2016) Intracellular $\mathrm{Ca}(2+)$ signaling and $\mathrm{Ca}(2+)$ microdomains in the control of cell survival, apoptosis and autophagy. Cell Calcium 60 (2):74-87. doi:10.1016/j.ceca.2016.04.005

110. Shinkai Y, Kaji T (2012) Cellular defense mechanisms against lead toxicity in the vascular system. Biol Pharm Bull 35 (11):1885-91

111. Peyrou M, Cribb AE (2007) Effect of endoplasmic reticulum stress preconditioning on cytotoxicity of clinically relevant nephrotoxins in renal cell lines. Toxicol In Vitro 21 (5):878-86. doi:10.1016/j.tiv.2007.03.001

112. Qian Y, Falahatpisheh MH, Zheng Y, Ramos KS, Tiffany-Castiglioni E (2001) Induction of $78 \mathrm{kD}$ glucoseregulated protein (GRP78) expression and redox-regulated transcription factor activity by lead and mercury in C6 rat glioma cells. Neurotox Res 3 (6):581-9

113. Chandrika BB, Yang C, Ou Y, Feng X, Muhoza D, Holmes AF, Theus S, Deshmukh S, Haun RS, Kaushal GP (2015) Endoplasmic Reticulum Stress-Induced Autophagy Provides Cytoprotection from Chemical Hypoxia and Oxidant Injury and Ameliorates Renal Ischemia-Reperfusion Injury. PLoS One 10 (10):e0140025. doi:10.1371/journal.pone.0140025 
114. Qian Y, Harris ED, Zheng Y, Tiffany-Castiglioni E (2000) Lead targets GRP78, a molecular chaperone, in C6 rat glioma cells. Toxicol Appl Pharmacol 163 (3):260-6. doi:10.1006/taap.1999.8878

115. Nagasawa H, Little JB (1992) Induction of sister chromatid exchanges by extremely low doses of alphaparticles. Cancer Res 52 (22):6394-6

116. Hamada N, Matsumoto H, Hara T, Kobayashi Y (2007) Intercellular and intracellular signaling pathways mediating ionizing radiation-induced bystander effects. J Radiat Res 48 (2):87-95

117. Mothersill C, Seymour C (2004) Radiation-induced bystander effects and adaptive responses --the Yin and Yang of low dose radiobiology? Mutat Res 568 (1):121-8. doi:10.1016/j.mrfmmm.2004.06.050

118. Iyer R, Lehnert BE (2002) Low dose, low-LET ionizing radiation-induced radioadaptation and associated early responses in unirradiated cells. Mutat Res 503 (1-2):1-9

119. Nobler MP (1969) The abscopal effect in malignant lymphoma and its relationship to lymphocyte circulation. Radiology 93 (2):410-2. doi:10.1148/93.2.410

120. Xue LY, Butler NJ, Makrigiorgos GM, Adelstein SJ, Kassis AI (2002) Bystander effect produced by radiolabeled tumor cells in vivo. Proc Natl Acad Sci U S A 99 (21):13765-70. doi:10.1073/pnas.182209699

121. Kassis AI (2004) In vivo validation of the bystander effect. Hum Exp Toxicol 23 (2):71-3

122. Morgan WF (2003) Non-targeted and delayed effects of exposure to ionizing radiation: II. Radiationinduced genomic instability and bystander effects in vivo, clastogenic factors and transgenerational effects. Radiat Res 159 (5):581-96

123. Azzam EI, de Toledo SM, Gooding T, Little JB (1998) Intercellular communication is involved in the bystander regulation of gene expression in human cells exposed to very low fluences of alpha particles. Radiat Res 150 (5):497-504

124. Azzam EI, de Toledo SM, Little JB (2001) Direct evidence for the participation of gap junction-mediated intercellular communication in the transmission of damage signals from alpha -particle irradiated to nonirradiated cells. Proc Natl Acad Sci U S A 98 (2):473-8. doi:10.1073/pnas.011417098

125. Iyer R, Lehnert BE, Svensson R (2000) Factors underlying the cell growth-related bystander responses to alpha particles. Cancer Res 60 (5):1290-8

126. Mothersill C, Seymour CB (1998) Cell-cell contact during gamma irradiation is not required to induce a bystander effect in normal human keratinocytes: evidence for release during irradiation of a signal controlling survival into the medium. Radiat Res 149 (3):256-62

127. Portess DI, Bauer G, Hill MA, O'Neill P (2007) Low-dose irradiation of nontransformed cells stimulates the selective removal of precancerous cells via intercellular induction of apoptosis. Cancer Res 67 (3):1246-53. doi:10.1158/0008-5472.CAN-06-2985

128. Han W, Zhu L, Jiang E, Wang J, Chen S, Bao L, Zhao Y, Xu A, Yu Z, Wu L (2007) Elevated sodium chloride concentrations enhance the bystander effects induced by low dose alpha-particle irradiation. Mutat Res 624 (1-2):124-31. doi:10.1016/j.mrfmmm.2007.04.010

129. Ma S, Liu X, Jiao B, Yang Y (2010) Low-dose radiation-induced responses: focusing on epigenetic regulation. Int J Radiat Biol 86 (7):517-28. doi:10.3109/09553001003734592

130. Raiche J, Rodriguez-Juarez R, Pogribny I, Kovalchuk O (2004) Sex- and tissue-specific expression of maintenance and de novo DNA methyltransferases upon low dose X-irradiation in mice. Biochem Biophys Res Commun 325 (1):39-47. doi:10.1016/j.bbrc.2004.10.002

131. Pogribny I, Raiche J, Slovack M, Kovalchuk O (2004) Dose-dependence, sex- and tissue-specificity, and persistence of radiation-induced genomic DNA methylation changes. Biochem Biophys Res Commun 320 (4):1253-61. doi:10.1016/j.bbrc.2004.06.081

132. Dickey JS, Zemp FJ, Martin OA, Kovalchuk O (2011) The role of miRNA in the direct and indirect effects of ionizing radiation. Radiat Environ Biophys 50 (4):491-9. doi:10.1007/s00411-011-0386-5

133. Xu S, Ding N, Pei H, Hu W, Wei W, Zhang X, Zhou G, Wang J (2014) MiR-21 is involved in radiationinduced bystander effects. RNA Biol 11 (9):1161-70. doi:10.4161/rna.34380

134. Xu S, Wang J, Ding N, Hu W, Zhang X, Wang B, Hua J, Wei W, Zhu Q (2015) Exosome-mediated microRNA transfer plays a role in radiation-induced bystander effect. RNA Biol 12 (12):1355-63. doi:10.1080/15476286.2015.1100795

135. Asur RS, Thomas RA, Tucker JD (2009) Chemical induction of the bystander effect in normal human lymphoblastoid cells. Mutat Res 676 (1-2):11-6. doi:10.1016/j.mrgentox.2009.02.012

136. Alexandre J, Hu Y, Lu W, Pelicano H, Huang P (2007) Novel action of paclitaxel against cancer cells: bystander effect mediated by reactive oxygen species. Cancer Res 67 (8):3512-7. doi:10.1158/00085472.CAN-06-3914

137. Demidem A, Morvan D, Madelmont JC (2006) Bystander effects are induced by CENU treatment and associated with altered protein secretory activity of treated tumor cells: a relay for chemotherapy? Int J Cancer 119 (5):992-1004. doi:10.1002/ijc.21761 
138. Rugo RE, Almeida KH, Hendricks CA, Jonnalagadda VS, Engelward BP (2005) A single acute exposure to a chemotherapeutic agent induces hyper-recombination in distantly descendant cells and in their neighbors. Oncogene 24 (32):5016-25. doi:10.1038/sj.onc.1208690

139. Klaassen CD, Liu J (1998) Metallothionein transgenic and knock-out mouse models in the study of cadmium toxicity. J Toxicol Sci 23 Supp12:97-102

140. Myers JP, Zoeller RT, vom Saal FS (2009) A clash of old and new scientific concepts in toxicity, with important implications for public health. Environ Health Perspect 117 (11):1652-5. doi:10.1289/ehp.0900887

141. Nair AR, Lee WK, Smeets K, Swennen Q, Sanchez A, Thevenod F, Cuypers A (2015) Glutathione and mitochondria determine acute defense responses and adaptive processes in cadmium-induced oxidative stress and toxicity of the kidney. Arch Toxicol 89 (12):2273-89. doi:10.1007/s00204-014-1401-9

142. Poisson C, Stefani J, Manens L, Delissen O, Suhard D, Tessier C, Dublineau I, Gueguen Y (2014) Chronic uranium exposure dose-dependently induces glutathione in rats without any nephrotoxicity. Free Radic Res 48 (10):1218-31. doi:10.3109/10715762.2014.945441

143. Gueguen Y, Rouas C, Monin A, Manens L, Stefani J, Delissen O, Grison S, Dublineau I (2014) Molecular, cellular, and tissue impact of depleted uranium on xenobiotic-metabolizing enzymes. Arch Toxicol 88 (2):227-39. doi:10.1007/s00204-013-1145-y

144. Korashy HM, El-Kadi AO (2006) Transcriptional regulation of the NAD(P)H:quinone oxidoreductase 1 and glutathione S-transferase ya genes by mercury, lead, and copper. Drug Metab Dispos 34 (1):152-65

145. Kataoka T (2013) Study of antioxidative effects and anti-inflammatory effects in mice due to low-dose Xirradiation or radon inhalation. J Radiat Res 54 (4):587-96. doi:10.1093/jrr/rrs 141

146. Kojima S, Nakayama K, Ishida H (2004) Low dose gamma-rays activate immune functions via induction of glutathione and delay tumor growth. J Radiat Res 45 (1):33-9

147. Nomura T, Yamaoka K (1999) Low-dose gamma-ray irradiation reduces oxidative damage induced by CCl4 in mouse liver. Free Radic Biol Med 27 (11-12):1324-33

148. Bravard A, Luccioni C, Moustacchi E, Rigaud O (1999) Contribution of antioxidant enzymes to the adaptive response to ionizing radiation of human lymphoblasts. Int J Radiat Biol 75 (5):639-45

149. Cui J, Yang G, Pan Z, Zhao Y, Liang X, Li W, Cai L (2017) Hormetic Response to Low-Dose Radiation: Focus on the Immune System and Its Clinical Implications. Int J Mol Sci 18 (2). doi:10.3390/ijms 18020280

150. Rodel F, Frey B, Gaipl U, Keilholz L, Fournier C, Manda K, Schollnberger H, Hildebrandt G, Rodel C (2012) Modulation of inflammatory immune reactions by low-dose ionizing radiation: molecular mechanisms and clinical application. Curr Med Chem 19 (12):1741-50

151. Scott BR (2014) Radiation-hormesis phenotypes, the related mechanisms and implications for disease prevention and therapy. J Cell Commun Signal 8 (4):341-52. doi:10.1007/s 12079-014-0250-x

152. Ina Y, Sakai K (2005) Activation of immunological network by chronic low-dose-rate irradiation in wildtype mouse strains: analysis of immune cell populations and surface molecules. Int J Radiat Biol 81 (10):721-9. doi:10.1080/09553000500519808

153. Luckey TD (1982) Physiological benefits from low levels of ionizing radiation. Health Phys 43 (6):771-89

154. Bogdandi EN, Balogh A, Felgyinszki N, Szatmari T, Persa E, Hildebrandt G, Safrany G, Lumniczky K (2010) Effects of low-dose radiation on the immune system of mice after total-body irradiation. Radiat Res 174 (4):480-9. doi:10.1667/RR2160.1

155. Klug F, Prakash H, Huber PE, Seibel T, Bender N, Halama N, Pfirschke C, Voss RH, Timke C, Umansky L, Klapproth K, Schakel K, Garbi N, Jager D, Weitz J, Schmitz-Winnenthal H, Hammerling GJ, Beckhove P (2013) Low-dose irradiation programs macrophage differentiation to an iNOS(+)/M1 phenotype that orchestrates effective $\mathrm{T}$ cell immunotherapy. Cancer Cell 24 (5):589-602. doi:10.1016/j.ccr.2013.09.014

156. Wunderlich R, Ernst A, Rodel F, Fietkau R, Ott O, Lauber K, Frey B, Gaipl US (2015) Low and moderate doses of ionizing radiation up to 2 Gy modulate transmigration and chemotaxis of activated macrophages, provoke an anti-inflammatory cytokine milieu, but do not impact upon viability and phagocytic function. Clin Exp Immunol 179 (1):50-61. doi:10.1111/cei.12344

157. Vieira Dias J, Gloaguen C, Kereselidze D, Manens L, Tack K, Ebrahimian TG (2018) Gamma Low-DoseRate Ionizing Radiation Stimulates Adaptive Functional and Molecular Response in Human Aortic Endothelial Cells in a Threshold-, Dose-, and Dose Rate-Dependent Manner. Dose Response 16 (1):1559325818755238. doi:10.1177/1559325818755238

158. Budras KD, Hartung K, Munzer BM (1986) [Light and electron microscopy studies of the effect of roentgen irradiation on the synovial membrane of the inflamed knee joint]. Berl Munch Tierarztl Wochenschr $99(5): 148-52$ 
159. Pandey R, Shankar BS, Sharma D, Sainis KB (2005) Low dose radiation induced immunomodulation: effect on macrophages and $\mathrm{CD} 8+\mathrm{T}$ cells. Int $\mathrm{J}$ Radiat Biol 81 (11):801-12. doi:10.1080/09553000500531886

160. Trott KR, Parker R, Seed MP (1995) [The effect of x-rays on experimental arthritis in the rat]. Strahlenther Onkol 171 (9):534-8

161. Hildebrandt G, Radlingmayr A, Rosenthal S, Rothe R, Jahns J, Hindemith M, Rodel F, Kamprad F (2003) Low-dose radiotherapy (LD-RT) and the modulation of iNOS expression in adjuvant-induced arthritis in rats. Int J Radiat Biol 79 (12):993 - 1001. doi:10.1080/09553000310001636639

162. Schaue D, Jahns J, Hildebrandt G, Trott KR (2005) Radiation treatment of acute inflammation in mice. Int J Radiat Biol 81 (9):657-67. doi:10.1080/09553000500385556

163. Nakatsukasa H, Tsukimoto M, Ohshima Y, Tago F, Masada A, Kojima S (2008) Suppressing effect of lowdose gamma-ray irradiation on collagen-induced arthritis. J Radiat Res 49 (4):381-9

164. Zaiss MM, Frey B, Hess A, Zwerina J, Luther J, Nimmerjahn F, Engelke K, Kollias G, Hunig T, Schett G, David JP (2010) Regulatory T cells protect from local and systemic bone destruction in arthritis. J Immunol 184 (12):7238-46. doi:10.4049/jimmunol.0903841

165. Frey B, Gaipl US, Sarter K, Zais s MM, Stillkrieg W, Rodel F, Schett G, Herrmann M, Fietkau R, Keilholz L (2009) Whole body low dose irradiation improves the course of beginning polyarthritis in human TNF-trans genic mice. Autoimmunity 42 (4):346-8

166. Aunapuu M, Pechter U, Gerskevits E, Marjamagi MM, Suuroja S, Arend A, Kolts I, Kuhnel W, Ots M (2004) Low-dose radiation modifies the progression of chronic renal failure. Ann Anat 186 (3):277-82. doi:10.1016/S0940-9602(04)80017-7

167. Pathak CM, Avti PK, Kumar S, Khanduja KL, Sharma SC (2007) Whole body exposure to low-dose gamma radiation promotes kidney antioxidant status in Balb/c mice. J Radiat Res 48 (2):113-20

168. Ruiz S, Pergola PE, Zager RA, Vaziri ND (2013) Targeting the transcription factor Nrf2 to ameliorate oxidative stress and inflammation in chronic kidney disease. Kidney Int 83 (6):1029-41. doi:10.1038/ki.2012.439

169. Yoh K, Itoh K, Enomoto A, Hirayama A, Yamaguchi N, Kobayashi M, Morito N, Koyama A, Yamamoto M, Takahashi S (2001) Nrf2-deficient female mice develop lupus-like autoimmune nephritis. Kidney Int 60 (4):1343-53. doi:10.1046/j. 1523-1755.2001.00939.x

170. Yoh K, Hirayama A, Ishizaki K, Yamada A, Takeuchi M, Yamagishi S, Morito N, Nakano T, Ojima M, Shimohata H, Itoh K, Takahashi S, Yamamoto M (2008) Hyperglycemia induces oxidative and nitrosative stress and increases renal functional impairment in Nrf2-deficient mice. Genes Cells 13 (11):1159-70. doi:10.1111/j.1365-2443.2008.01234.x

171. Bettelli E, Carrier Y, Gao W, Korn T, Strom TB, Oukka M, Weiner HL, Kuchroo VK (2006) Reciprocal developmental pathways for the generation of pathogenic effector TH17 and regulatory T cells. Nature 441 (7090):235-8. doi:10.1038/nature04753

172. Farooque A, Mathur R, Verma A, Kaul V, Bhatt AN, Adhikari JS, Afrin F, Singh S, Dwarakanath BS (2011) Low-dose radiation therapy of cancer: role of immune enhancement. Expert Rev Anticancer Ther 11 (5):791-802. doi:10.1586/era.10.217

173. Weng L, Williams RO, Vieira PL, Screaton G, Feldmann M, Dazzi F (2010) The therapeutic activity of low-dose irradiation on experimental arthritis depends on the induction of endogenous regulatory $\mathrm{T}$ cell activity. Ann Rheum Dis 69 (8):1519-26. doi:10.1136/ard.2009.121111

174. Ebrahimian T, Le Gallic C, Stefani J, Dublineau I, Yentrapalli R, Harms-Ringdahl M, Haghdoost S (2015) Chronic Gamma-Irradiation Induces a Dose-Rate-Dependent Pro-inflammatory Response and Associated Loss of Function in Human Umbilical Vein Endothelial Cells. Radiat Res 183 (4):447-54. doi:10.1667/RR13732.1

175. Hoving S, Heeneman S, Gijbels MJ, te Poele JA, Russell NS, Daemen MJ, Stewart FA (2008) Single-dose and fractionated irradiation promote initiation and progression of atherosclerosis and induce an inflammatory plaque phenotype in ApoE(-/-) mice. Int J Radiat Oncol Biol Phys 71 (3):848-57. doi:10.1016/j.ijrobp.2008.02.031

176. AGIR (2010) Report of the independent Advisory Group on Ionising Radiation - Circulatory Disease Risk. Documents of the Health Protection Agency. Radiation, Chemical and Environmental Hazards:Chilton, Doc HPA, RCE-16, 1-116

177. Le Gallic C, Phalente Y, Manens L, Dublineau I, Benderitter M, Gueguen Y, Lehoux S, Ebrahimian TG (2015) Chronic Internal Exposure to Low Dose 137Cs Induces Positive Impact on the Stability of Atherosclerotic Plaques by Reducing Inflammation in ApoE-/- Mice. PLoS One 10 (6):e0128539. doi:10.1371/journal.pone.0128539

178. Mitchel RE, Hasu M, Bugden M, Wyatt H, Little MP, Gola A, Hildebrandt G, Priest ND, Whitman SC (2011) Low-dose radiation exposure and atherosclerosis in ApoE(-)/(-) mice. Radiat Res 175 (5):66576. doi:10.1667/RR2176.1 
179. Zhang C, Jin S, Guo W, Li C, Li X, Rane MJ, Wang G, Cai L (2011) Attenuation of diabetes -induced cardiac inflammation and pathological remodeling by low-dose radiation. Radiat Res 175 (3):307-21. doi:10.1667/RR1950.1

180. Chen W, Xu X, Bai L, Padilla MT, Gott KM, Leng S, Tellez CS, Wilder JA, Belinsky SA, Scott BR, Lin Y (2012) Low-dose gamma-irradiation inhibits IL-6 secretion from human lung fibroblasts that promotes bronchial epithelial cell transformation by cigarette-smoke carcinogen. Carcinogenesis 33 (7):1368-74. doi:10.1093/carcin/bgs 159

181. Bruce VR, Belinsky SA, Gott K, Liu Y, March T, Scott B, Wilder J (2012) Low-dose gamma-radiation inhibits benzo[a]pyrene-induced lung adenoma development in a/j mice. Dose Response 10 (4):516-26. doi:10.2203/dose-response.12-040.Bruce

182. Calabrese EJ, Baldwin LA, Kostecki PT, Potter TL (1997) A toxicologically based weight-of-evidence methodology for the relative ranking of chemicals of endocrine disruption potential. Regul Toxicol Pharmacol 26 (1 Pt 1):36-40. doi:10.1006/rtph.1997.1115

183. Miller MF, Goodson WH, Manjili MH, Kleinstreuer N, Bisson WH, Lowe L (2017) Low-Dose Mixture Hypothesis of Carcinogenesis Workshop: Scientific Underpinnings and Research Recommendations. Environ Health Perspect 125 (2):163-169. doi:10.1289/EHP411

184. Dimova EG, Bryant PE, Chankova SG (2008) Adaptive response: Some underlying mechanisms and open questions. Genet. Mol. Biol. 31:396-408

185. Azzam EI, de Toledo SM, Waker AJ, Little JB (2000) High and low fluences of alpha-particles induce a G1 checkpoint in human diploid fibroblasts. Cancer Res 60 (10):2623-31 
Table 1. Development of adaptation for several signaling pathways ind uced by low dose irradiation and chemicals (relevant references indicated)

\begin{tabular}{|c|c|c|}
\hline Signaling pathways & $\begin{array}{c}\text { Ionizing radiation } \\
\text { types }\end{array}$ & Chemical compounds \\
\hline DNA damage repair ( $p 53$, ATM, PARP) & $\begin{array}{c}\alpha, \beta, X, \gamma[9,27,32 \\
118,42,123]\end{array}$ & alkylating agent [29] \\
\hline Nrf2 antioxidant pathway & $\begin{array}{c}\alpha, x[54,145,68, \\
148]\end{array}$ & $\begin{array}{l}\text { Sulforaphane, heavy metals, } \\
\text { thiol }[45,46,144,66]\end{array}$ \\
\hline NF- $\kappa B$ inflammatory pathway & $\begin{array}{c}\gamma, \times[61-63,65,67, \\
152]\end{array}$ & Thiol [66] \\
\hline MAPK (AKT, ERK, JNK) pathway & $\gamma, x[73-75,100]$ & Alkylating agent [75] \\
\hline Autophagy & $\gamma[87,88]$ & CBZ, heavy metals $[91,92]$ \\
\hline CyclinB1/CDK1 & $\alpha, \mathrm{X}[101,123,185]$ & Not known \\
\hline Apoptosis (Bax/Bcl2, Wnt/ $\beta$ catenin) & $\gamma[103,102]$ & $\mathrm{Cd}[141]$ \\
\hline UPR response & Not known & $\begin{array}{c}\text { Nephrotoxin drugs, } \mathrm{Pb} \\
{[111,113,114]}\end{array}$ \\
\hline Bystander (diffusible factors) & $\alpha, \gamma[118,125]$ & $\mathrm{Cd}[139]$ \\
\hline
\end{tabular}

